\title{
Distribution and Integration of Military Settlements' Cultural Heritage in the Large Pass City of the Great Wall in the Ming Dynasty: A Case Study of Juyong Pass Defense Area
}

\author{
Yukun Zhang ${ }^{1,2}$, Songyang $\mathrm{Li}^{1,2}$, Lifeng Tan ${ }^{1,2}$ and Jiayin Zhou ${ }^{1,2, * \mathbb{D}}$ \\ 1 School of Architecture, Tianjin University, No. 92 Weijin Road, Nankai District, Tianjin 300072, China; \\ zjy_tju1994@163.com (Y.Z.); Lsy_liuhe@yeah.net (S.L.); arch_lftan@126.com (L.T.) \\ 2 Key Laboratory of Department of Culture and Tourism of Information Technology of Architectural Heritage \\ Inheritance, Tianjin University, No. 92 Weijin Road, Nankai District, Tianjin 300072, China \\ * Correspondence: mmszhou@foxmail.com
}

Citation: Zhang, Y.; Li, S.; Tan, L.; Zhou, J. Distribution and Integration of Military Settlements' Cultural Heritage in the Large Pass City of the Great Wall in the Ming Dynasty: A Case Study of Juyong Pass Defense Area. Sustainability 2021, 13, 7166. https://doi.org/10.3390/su13137166

Academic Editor: Shangyi Zhou

Received: 16 April 2021

Accepted: 4 June 2021

Published: 25 June 2021

Publisher's Note: MDPI stays neutral with regard to jurisdictional claims in published maps and institutional affiliations.

Copyright: (c) 2021 by the authors. Licensee MDPI, Basel, Switzerland. This article is an open access article distributed under the terms and conditions of the Creative Commons Attribution (CC BY) license (https:/ / creativecommons.org/licenses/by/ $4.0 /)$.

\begin{abstract}
The Great Wall of China is more than a wall: it is an extensive cultural route. Pass cities, which are usually large defensive fortresses overseeing an entire fortified area, are an essential part of this heritage and are at the core of the Great Wall's defense system. Juyong Pass was the closest Pass city to Beijing during the Ming Dynasty when the Great Wall reached its peak. It consisted of five regions-south, east, north, west, and central—that form three fortification levels: core castle, Bao city, and End facility. Based on the Juyong defense area military settlements database, this paper applied spatial analysis methods and found that more than half of the military's resources for the whole defense area were focused on the western part of the wall, which formed another military core alongside Juyong Pass city. However, the current conservation strategy only focuses on Juyong Pass itself, neglecting the settlements in the western part, thereby destroying the integrity of the Great Wall's heritage. By clarifying the distribution of cultural heritage in this area, we hope to encourage the preservation of many fortifications according to their authentic historical sphere of control and provide a reference for the sustainable integration of resources along the significant cultural routes of the Great Wall.
\end{abstract}

Keywords: the Great Wall during the Ming dynasty; Juyong Pass; Juyong defense area; pass city

\section{Introduction}

During the drafting and adoption of the Charter on Cultural Routes by the International Council of Monuments and Sites (ICOMOS) from 2005 to 2008 [1], Chinese academics discussed constructing a national linear heritage network in China and agreed that the Great Wall should be considered a cultural route [2]. As such, it was inscribed on the World Heritage List in 1987 [3]. The Great Wall has tangible cultural heritage (castles) as well as intangible cultural heritage (construction techniques) [4]. The Great Wall Protection Master Plan, jointly issued by the National Culture Heritage Administration of China and the Ministry of Culture and Tourism in 2019, promotes a holistic and systematic conservation strategy and the delineation of a more precise scope of protection [5]. The scope of the master plan is similar to UNESCO's "buffer zone" concept for world heritage sites [6], which for the Great Wall is currently marked as $4800.8 \mathrm{ha}$, which is about twice its area (2151.55 ha) [3]. The buffer zone is based on 21,000 km [7] of wall sites, but many military settlements far from the wall are not included, which leads to urbanization, pollution, and a lack of awareness of cultural heritage protection. However, it is hard to define the scope of protection before clarifying the Great Wall defense system's entire heritage composition and relationship. For a long time, omissions in system design have limited the conservation of the Great Wall to a single wall.

The surviving Great Wall sites include 22 historical regimes from 12 historical periods between 7 BC and 17 AD [7]. The Great Wall we see now was mostly built during the 
Ming dynasty (8851.8 km [8]) and is the best-preserved and most complex system. As a result of implementing the Dusi Weisuo (military administrative) system, defensive castles of different scales were set up throughout the country to form a tight military network. This network was particularly dense along the Great Wall and was divided into six levels: Town cities, Road cities, Wei cities, Suo cities, Bao cities, and End facilities (Figure 1) [9]. Horizontally, it consisted of nine large districts, each overseen by a Town city (similar to a provincial capital). Vertically, the Road city and Wei city were set up along the Great Wall for warning and battle, while the Suo city and Bao city were set up in the hinterland for farming and training [10]. Inside the fortress, different facilities such as beacon towers and post stations were set up as required. All these settlements were essential parts of the cultural heritage of the Ming Great Wall, and the sum of each castle buffer zone formed the primary protection range of the Ming Great Wall cultural line.
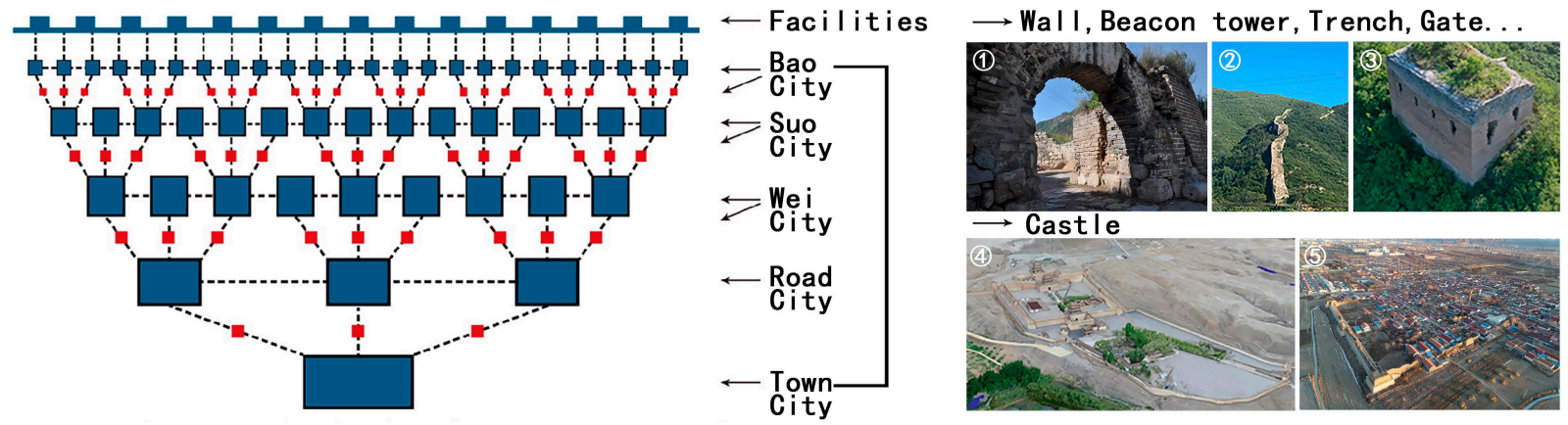

Figure 1. On the left: six levels of the Great Wall military system. On the right: (top l-r) (1) an arched door of south barbakan in Zhenbian Bao City, Heibei; (2) the Great Wall in the north of Hengling Bao City, Heibei; (3) beacon tower on the north mountain of Chadao Bao City, Beijing; (l-r bottom) (4) Jiayuguan Pass City, Gansu; (5) Tumu Bao City, Heibei.

In the Great Wall military system, castles that were set up at essential transportation hubs were called a "Pass city". This kind of castle could be at any of the six levels mentioned above, and the level determined its scale. A Pass city was usually very large, and it governed a military settlement for dozens of kilometers around to form a unified defensive zone [11], within which all fortification levels were coordinated and managed, thereby enhancing the Great Wall's effectiveness. The Pass city is the most decisive evidence that the Great Wall was a complex defense system [4]. Current research on the Ming Great Wall has focused more on the wall or a single site, with few studies on the synergistic relationship among a large number of regional Great Wall settlements. However, the complex hierarchical system, controlled by a large-scale Guancheng (Crown city), is the concentrated embodiment of this military strategy. The first series of important national sections of the Great Wall issued by the China National Cultural Heritage Administration at the end of 2020 contained 83 sections, 54 of which were Ming Dynasty sites, and 22 were Pass city-centered sections [12]. Prioritizing the protection of these Pass city defense areas helps overall resource integration along the Great Wall.

There are thousands of "passes" along the Great Wall, such as the famous Badaling and Jiayuguan, and for this study, Juyong Pass, also one of the larger and better-known Pass cities, was selected. It has three key qualities: first, it was the closest large fortress to Beijing, the Ming capital. As shown in Figure 2, three lines of the Great Wall were formed to the northwest of Beijing to guard the capital; Juyong Pass in the innermost part was called "the last line of defence for Beijing" [13]. Second, Juyong Pass is a Road city, the second-highest grade. Its jurisdiction was so large that it covered the most vital defense area to the northwest of Beijing, such as Badaling, as well as the Ming Tombs. Third, the scenic spots of the Great Wall, formed by Juyong and Badaling near Beijing, are the world's most famous. They have a significant social effect and can also provide a reference for the use of resources for all Great Wall Pass cities. 


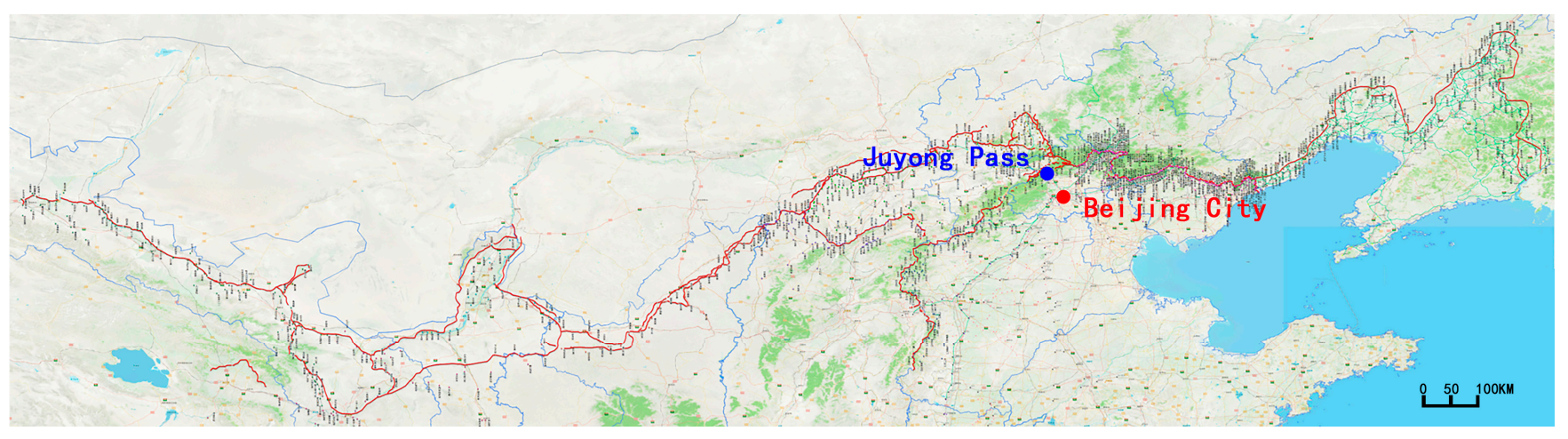

Figure 2. The location of Juyong Pass, Beijing, and the Great Wall in Ming dynasty (the base map from ArcGIS Online, copyright (C) 2020 Esri).

Although Juyong Pass is representative, there is still little research dedicated to it. On the one hand, existing studies have been conducted at the micro level, focusing mostly on certain remains of high heritage value within the Juyong Pass. For example, many archeologists and researchers of ancient Buddhist architecture have focused on the foundation of a pagoda (Yuntai), which is the oldest site in the castle ( 700 years old) and preserves valuable Buddhist reliefs [14-16]. On the other hand, since research on the system of military settlements has only gradually matured over the last decade, it has not yet covered the extent of its control over the large pass. Most of the findings about the Juyong Great Wall have appeared in research on the Great Wall in Beijing or Ji Zhen [17,18]. In 2010, Liu Shanshan, in her doctoral dissertation, expanded the geographic scope of the Juyong defense area for the first time by proposing the concept of the Juyong fortification zone and initially delineating the actual area of control of the Juyong Pass during the Ming Dynasty. Her dissertation also provided an important reference for the study of the defense zone of the large Ming fortifications. However, these studies still remain at the level of historical research, and no research has been conducted on the guiding role of such distribution characteristics or the military concerning he conservation and development of modern Great Wall heritage.

Meanwhile, the current exploitation of the Great Wall resources at Juyong is confined to itself. Liu determined that during the Ming Dynasty, Juyong Pass formed a defense zone and governed approximately $800 \mathrm{~km}^{2}$ [19]. As an overall framework for the Juyong defense area has not yet been established, many settlements belonging to Juyong Pass are not developed, are less well known, and have no tourism layout. In 2017, Yang and Meng first pointed out the lack of holistic protection of the Great Wall in the Juyong defense area, the seriousness of "isolation" and "marginalization", and the urgent need to develop a unified protection management mechanism [20]. Many secondary settlements also have well-preserved ruins of the Great Wall or castles (Figure 3). However, due to isolation and lack of infrastructure, the Great Wall resources' development around the Center, especially the western settlements, and Juyong Pass city, is very different. The integrity of the Great Wall heritage in the Juyong defense area has been damaged, and this damage will continue if conservation strategies are not adjusted in time. Therefore, clarifying the actual geographical scope of the Juyong defense area and the distribution of heritage resources can lead to the full excavation of the cultural value of Juyong Pass and effective resource integration. 

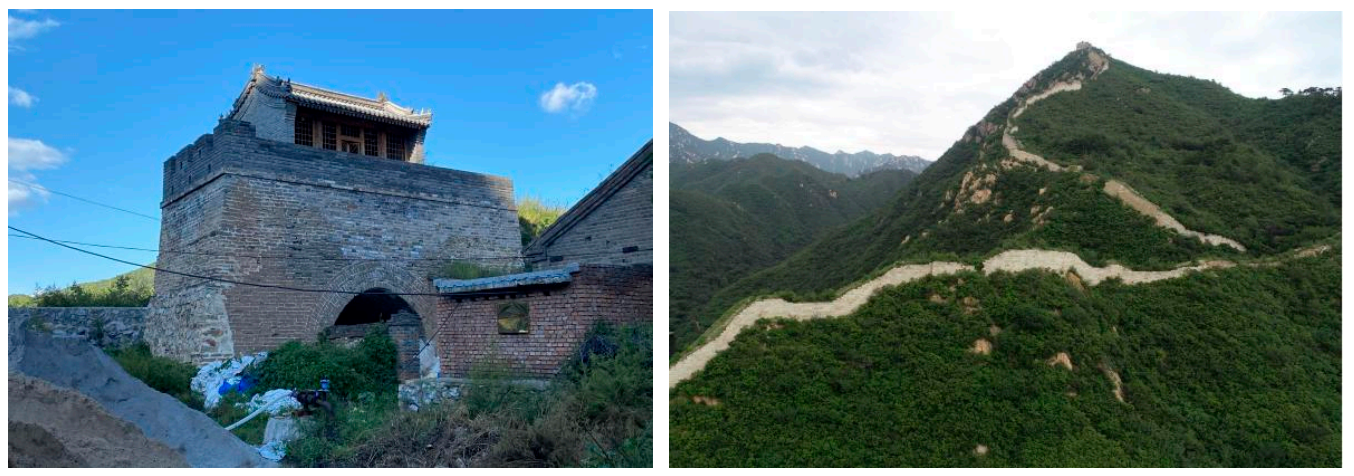

Figure 3. Other well-preserved sites of military settlements to the west of the Juyong defense area. On the left: the gate tower site of Hengling Bao City, Heibei. On the right: the wall site of Xishuiyu Bao City, Beijing.

\section{Materials and Methods}

\subsection{Study Area}

The construction of the Juyong defense area during the Ming Dynasty continued from the reign of Hongwu (1368-1398) to the reign of Jiajing (1522-1566). In 1550, during the Hundred Days' Change, construction of the Juyong defensive zone reached its peak during war with the Mongols. During this time, both the Annal of Xiguan and Annal of the four towns and three passes clearly described the Juyong defense area's scope [21]. According to modern administrative divisions, in addition to the Juyong scenic area in Changping District of Beijing, it also included numerous Great Wall cultural heritage sites in the Mentougou, Yanqing and Changping districts, and in Huailai town in Zhangjiakou (Figure 4).

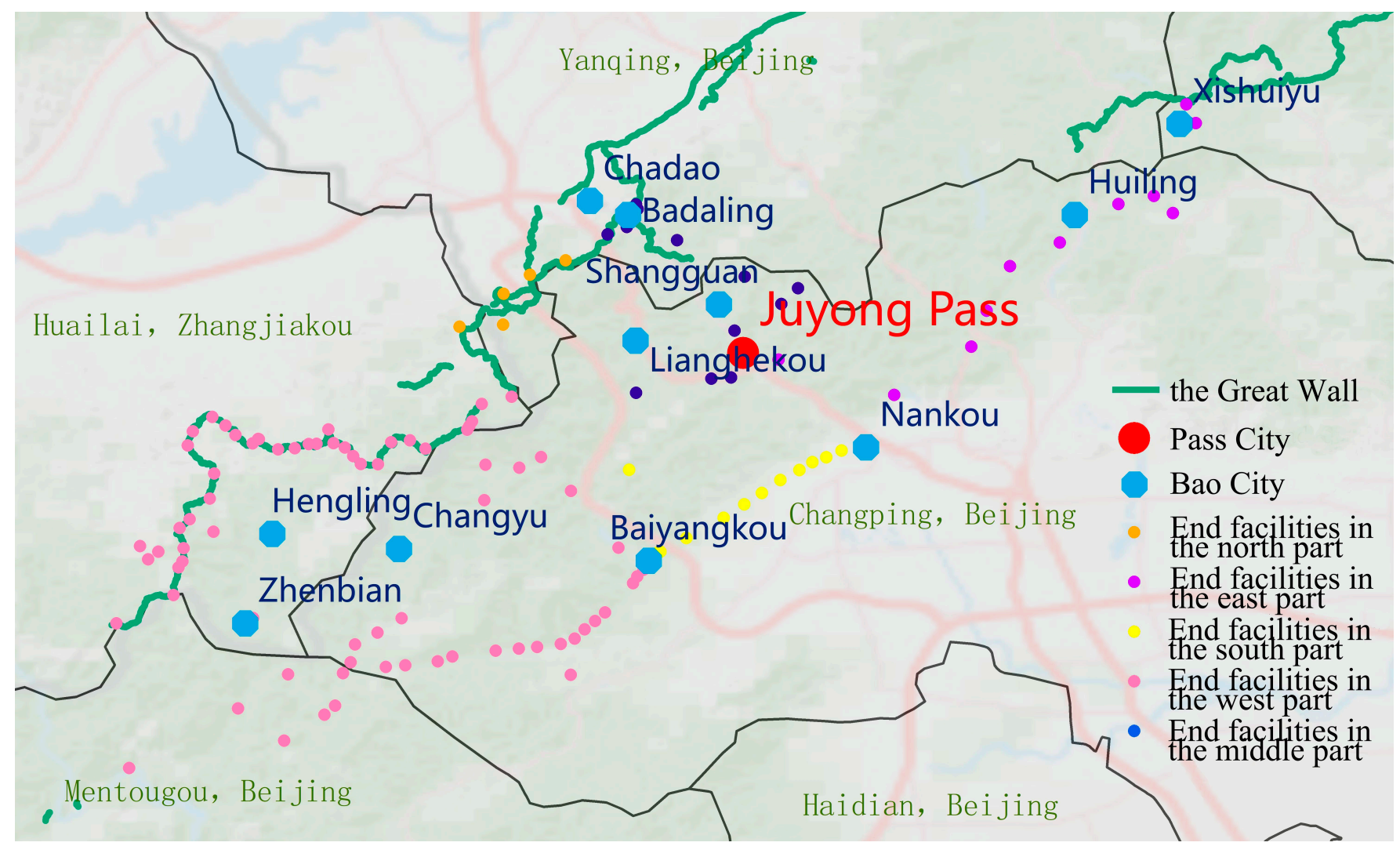

Figure 4. Military settlements in Juyong Pass defense area (the base map from ArcGIS Online, copyright @ 2020 Esri). 


\subsection{Data Sources}

Most historical information on the construction in the Juyong defense area, such as the size of castles and the number of troops, comes from the two annals [22,23] and from a small part of Ming Shi Lu, a chronicle of Ming Dynasty [24]. The military settlements' locations are based on site surveys and the Third National Heritage Census Report. Moreover, topographic information, such as elevation and slope, were obtained from ASTER GDEM-30 m elevation data [25].

\subsection{Methods}

\subsubsection{Construction of Military Settlement Database Based on ArcGIS}

According to the Annal of Xiguan [22], there were three levels in the military system of the Juyong defense area: Road cities, Bao cities, and End facilities. Juyong Pass, the only road city, had 13 Bao cities and 115 End facilities, divided into five regions: east, south, west, north, and central. By using this hierarchy as the main framework for the database, point sets were created in the ArcGIS platform by field research GPS positioning. By loading the DEM data, the geographical information of settlement points at all levels was extrapolated to the attribute table of the point map layer. Then, by sorting the historical data, the construction time, city scale, number of troops, and reserve of weapons were entered into the attribute table. The ArcGIS platform integrated spatial coordinates and the historical information of military settlements and then searched the category of target information to carry out a variety of spatial analyses. The geographical distribution is in Figure 4, and historical and geographic information is in Appendix A.

\subsubsection{Rank-Size Rule}

The Rank-Size rule is a practical application of the Hausdorff dimension in fractal theory and is the classical method for explaining urban resource distribution. Since Benoit B. Mandelbrot proposed fractal theory in 1975, this theory has been regarded as a significant change from conventional ways of thinking about spatial forms and has provided new and important norms and standards for spatial phenomena [26]. Hausdorff Dimension is one of the most important base models. It is used to measure N's size by the scale R. When R is infinite, $N(R)$ infinitely approaches a fixed value. The formula is

$$
\mathrm{N}(\mathrm{R}) \propto \mathrm{Cr}^{-\mathrm{D}}
$$

where $\mathrm{C}$ is a constant and $\mathrm{D}$ represents the fractal dimension of this object.

When applied to modern urban population problems, the number of people in a city and the city's position in the national urban population usually satisfy the Rank-Size rule or Zipf model. For example, a rank three city would have $1 / 3$ the population of a country's largest city, and a rank four city would have $\frac{1}{4}$ the population [27]. A double logarithmic coordinate scatter plot is created using the number of people in each city and the corresponding size order. The better the fit, the better the representation fits this model. The formula is

$$
\mathrm{P}(\mathrm{a})=\mathrm{Qa}^{-\mathrm{q}} \text { or } \log (\mathrm{P})=\log (\mathrm{Q})-\mathrm{q} \log (\mathrm{a})
$$

where $\mathrm{P}(\mathrm{a})$ is the size of the city's ranked population, $\mathrm{Q}$ is a constant and $\mathrm{q}$ is the Zipf value, indicating the sub-dimensional value of this city.

- At $q \infty$, there is only one element in the system;

- When $\mathrm{q}>1$, the quantity distribution is more dispersed: the system is not mature enough, and the monopoly of the first city is insufficient;

- When $\mathrm{q}=1$, the ratio between the size of the first city and the size of the last city is equal to the number of samples, and resource use is optimized;

- When $\mathrm{q}<1$, the quantity distribution concentrates in the middle order: the system is mature, but the monopoly of the first city is insufficient;

- When $\mathrm{q}=0$, every sample in the system is the same [28,29]. 
In practical data analysis, the fit of the actual data to the standard Zipf formula is calculated using a double logarithmic power to create a scatter plot to obtain the fit formula and the fit $R^{2}$. Numerically, $R^{2}$ is a dimensionless coefficient with a defined range between 0 and 1 . When $R^{2}$ is asymptotically close to 1 , the quantitative model is close to the ideal fractal system. Then, comparing q determines the quantitative distribution characteristics. Moreover, this study is about the traditional military settlements focused on their defensive ability, so it is better to replace the urban population with the number of troops [30].

\subsubsection{Voronoi}

The Voronoi algorithm is widely used in domain analysis and service area scope design. It consists of many irregular polygons also known as Thiessen polygons. Each Thiessen polygon contains only a single-point input feature. Any location within a Thiessen polygon is closer to its associated point than to any other point input feature [31]. Based on the set of military settlement points established in the ArcGIS platform, the Voronoi map can be calculated to determine each settlement's military jurisdiction. Opening the attribute sheet of the resulting layer will give the area (S) of each polygon [32,33].

Moreover, the point set's aggregation degree can be judged by calculating the $\mathrm{CV}$ index of $S$, which is the discrete coefficient (ratio of standard deviation to average value). There are three situations:

- When CV $>64 \%$, the area of each polygon varies greatly, and the point set is concentrically distributed;

- When $64 \% \geq C V \geq 33 \%$, the area of each polygon is moderate and the point set is randomly distributed;

- When $\mathrm{CV}<33 \%$, the area of each polygon varies little and the point set is uniformly distributed [30].

\section{Results}

\subsection{Clustering of Military Settlements}

3.1.1. Space Layout

The military settlements in the Juyong defense area are on the border between the mountains and the plains, with the Great Wall built along the Taihang Mountains, a natural barrier that defends Beijing. There are eight valley passes called "Taihang Baxing" (Figure 5), which are essential passageways into th Beijing Plain from the northwest. The Jundu Valley Pass, where Juyong Castle is located, is the closest and shortest way to Beijing. The Juyong defensive zone exists to guard this diplomatic, economic, and military route.

While the layout of the Ming Great Wall military settlements is usually longitudinal, with the settlements becoming more densely distributed the closer they are to the wall [34], the Juyong defense area was different. The whole defense area was clearly detached from the Great Wall boundary wall's mainline. The central Pass city and five defense parts joined together to form a belt based on the mountain. These formed four paths (Figure 6) parallel or perpendicular to the alignment of the mountains: two short, two long in one vertical and three horizontal layouts:

- On the west side of the defensive area and the north side of the Taihang Mountains, the western and northern settlements were built parallel to the mountains along the Great Wall.

- On the west side of the defensive area and the south side of the Taihang Mountains, the western and southern settlements were built parallel to the mountain trend along the line between the mountains and the Beijing Plain.

- In the central area, the northern and southern settlements were built perpendicular to the mountain trend, mainly central settlements and five castles on the canyon path.

- On the east side of the defensive area and the south side of the Taihang Mountains, the eastern settlements were built parallel to the mountains along a line between the mountains and the Beijing Plain. 


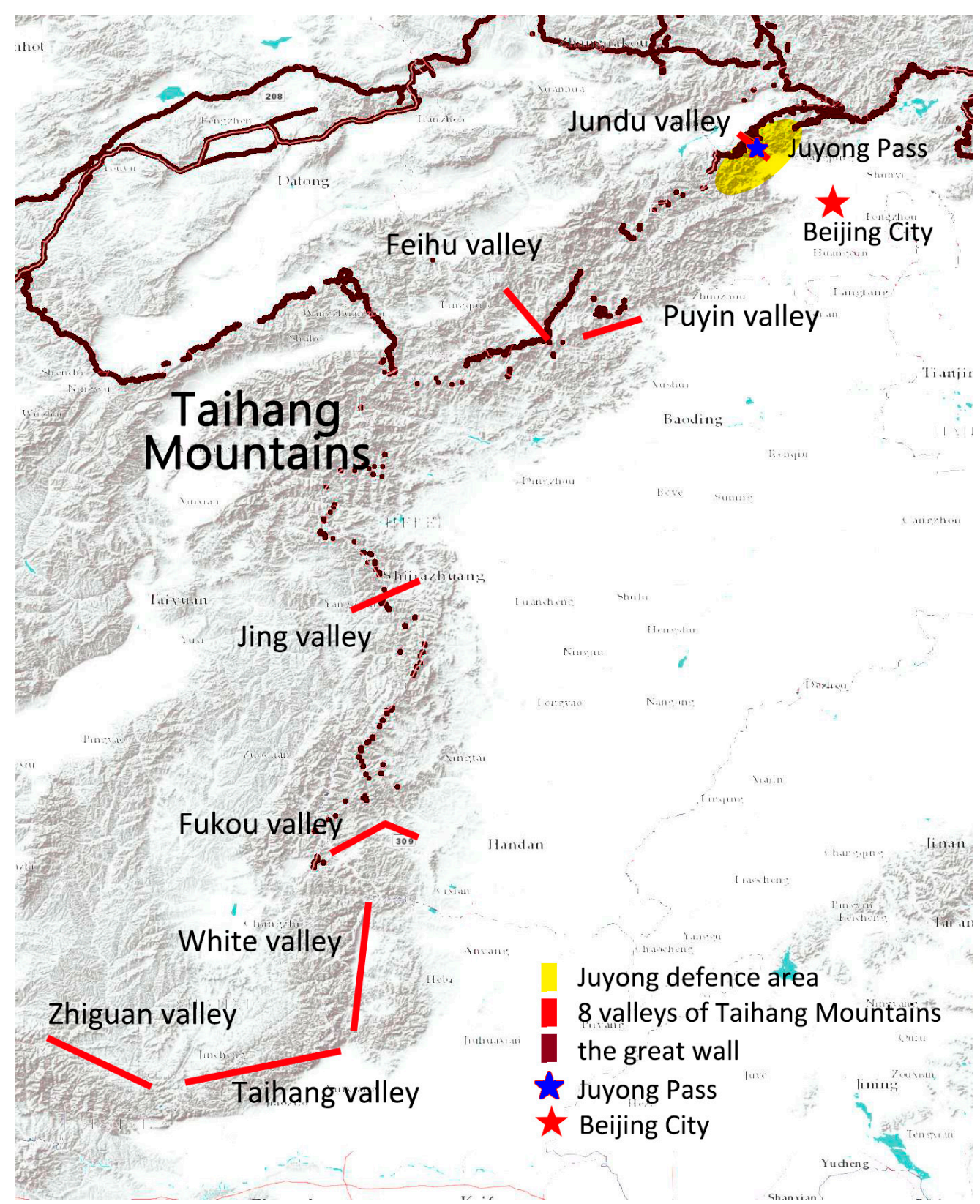

Figure 5. The location of Taihang Mountains and the 8 valley pass of Taihang. (The base map from ArcGIS Online, copyright (C) 2020 Esri.).

These four paths mainly rely on the Taihang Mountains and protect the Jundu valley pass. However, not all of them gathered in Jundu. According to the distribution area of pink settlement points in the map, the western settlements occupied more than half of the geographical range, greatly expanding the defense scope. 


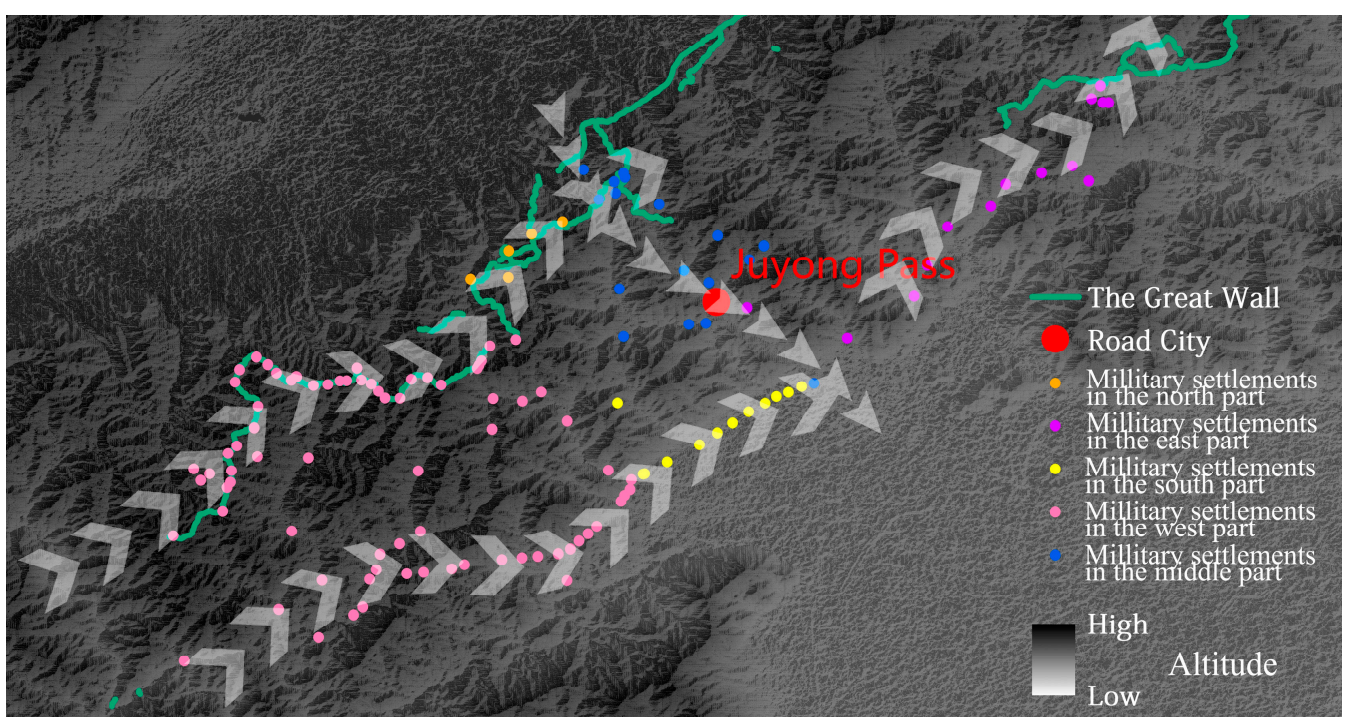

Figure 6. The relationship between the distribution of military settlements heritage and the terrain in Juyong defense area base map from ASTER GDEM-30 m elevation data).

\subsubsection{Distribution Density}

From a kernel density analysis of all the settlements in the database (Figure 7) it is clear that the density of settlements decreased from west to east, with the western part being the densest, followed by the middle, while the eastern military settlements were the sparsest. The highest density was found along the Great Wall to the northwest and in the area around Baiyangkou, both in the western part of the Juyong defense area. On the other hand, the density along the entire edge was much greater than in the hinterland. This defense area's edge consisted of smaller end-installations of lower rank and scale that had a better information transmission ability. The hinterland was dominated by large castles, which had an excellent ability to train troops to support the front line and were centrally located with good accessibility.

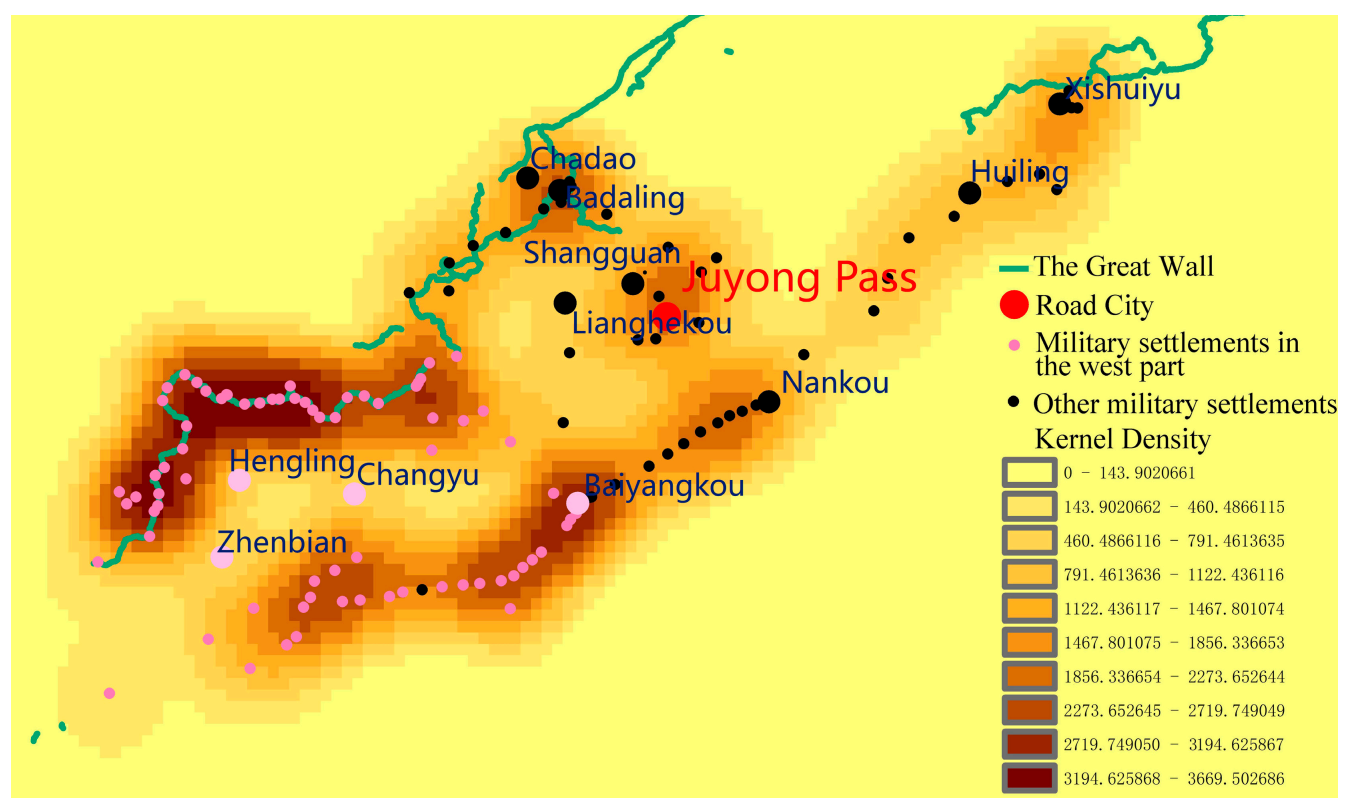

Figure 7. Kernel density of military settlements. 
To determine the control range of each military settlement, a Voronoi analysis was done for all points (Figure 8). As there was no other Great Wall fortification around the Juyong defense area and the infinite extension area of the polygon at the outermost edge was too large, the outermost polygon was removed. As a result, the average area of these polygons was $10.34 \mathrm{~km}^{2}$, which meant an average of about $10 \mathrm{~km}^{2}$ was under the jurisdiction of each military settlement. Moreover, the standard deviation was $11.25 \mathrm{~km}^{2}$, $\mathrm{CV}=10 \mathrm{~km}^{2} / 11.25 \mathrm{~km}^{2}=91.9 \%$, much larger than the critical value of $64 \%$. This meant that the settlement distribution in the Juyong defense area had significant aggregation characteristics. In particular, the polygon area controlled by Hengling, Zhenbian, and Changyu in the western hinterland was far larger than the one on the boundary and was even more extensive than the Juyong Pass, so the importance of the western fortification was no less than that of Juyong Pass City.

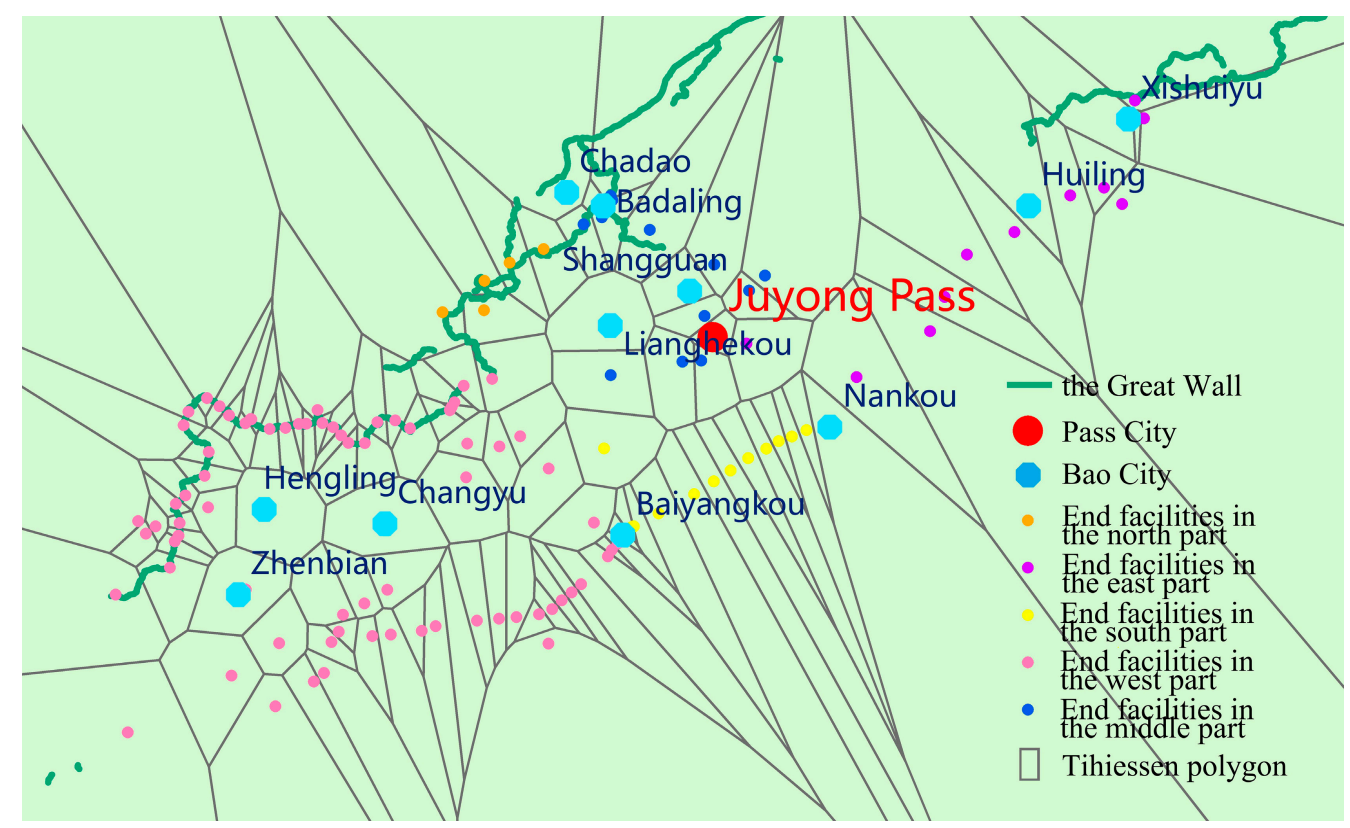

Figure 8. Thiessen polygon of military settlements.

\subsection{Clustering of Troops}

\subsubsection{Distribution Density}

Apart from the fortifications themselves, the number of troops was another indicator of the importance of these military settlements. From a kernel density analysis of all the settlements in the database from Appendix A (Figure 9), the number of troops in Juyong Pass and the four Bao cities (Hengling, Zhenbian, Changyu, and Baiyangkou) was much higher than for the other settlements. There were significant differences in the scale of the garrison in the Road cities' (average 3750), Bao cities' (average 281), and End facilities' (average of eight) three levels. However, on the whole, the total number of troops in the Juyong Pass and western settlements was equal, accounting for about $85 \%$ of the troops in this defense area, the core of the two major military forces (Figure 10). 


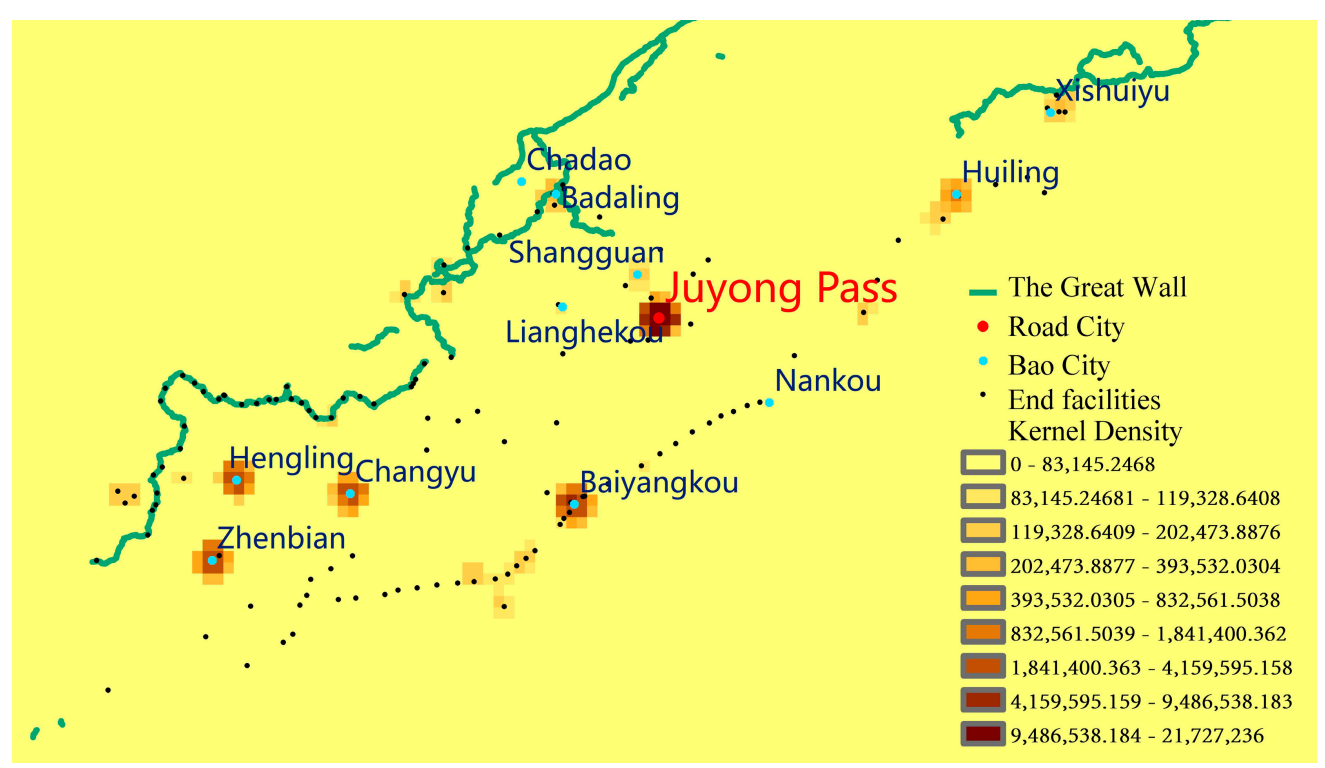

Figure 9. Kernel density of troops.

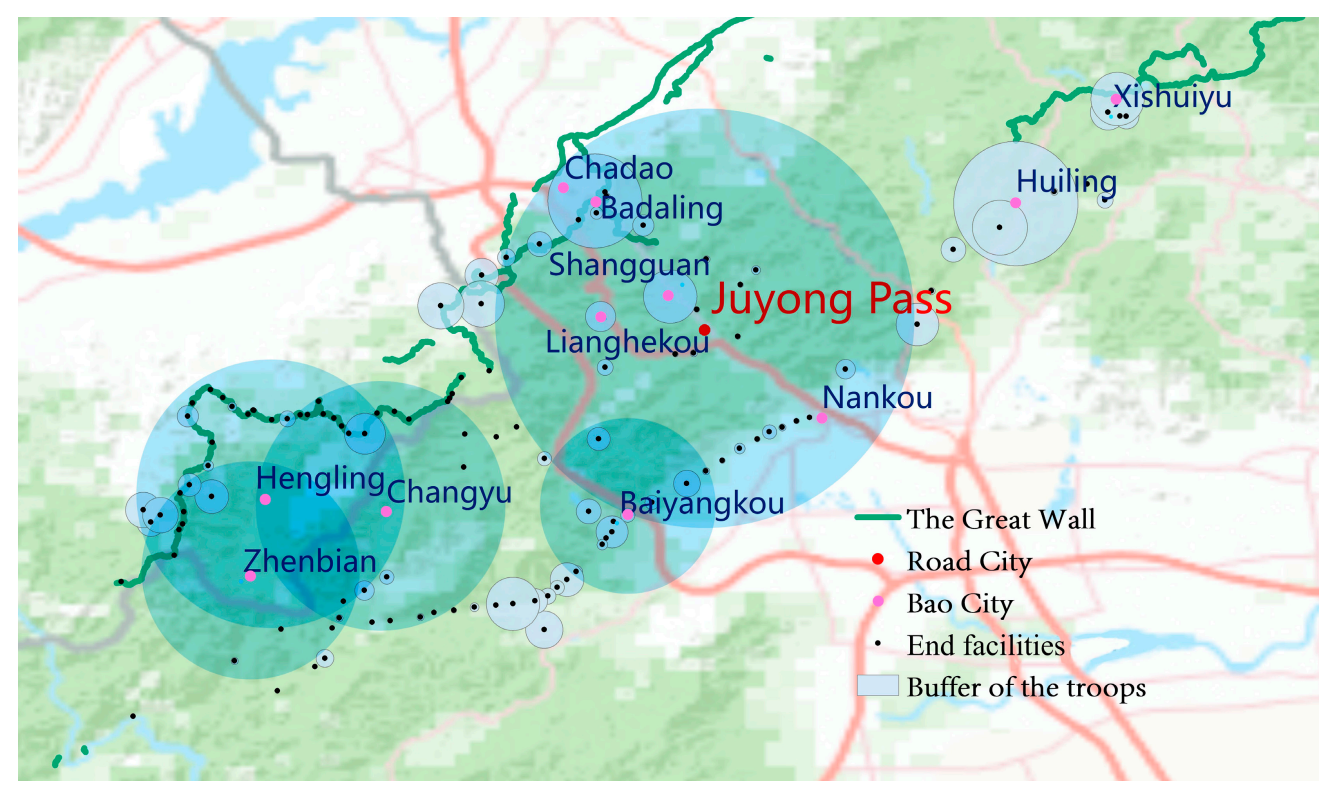

Figure 10. The circles show the difference in the number of garrisons among different levels of settlements (base map from ArcGIS Online, copyright (C) 2020 Esri).

\subsubsection{Quantitative Distribution}

Although troop distribution can be initially identified using ArcGIS kernel density analysis, it is still challenging to determine the degree of their concentration. Using the Rank-Size rule, all the non-zero settlements were ranked and a double logarithm power scatter plot was made (Table 1). For the Road city-Bao city-End facility three-level settlement, $R^{2}=0.9452$ (almost 1), which shows that the Zipf model is suitable for this set of data. The Zipf formula is $y=1918.5 x^{-1.513}$, and the $q$ is far greater than 1 , which means that the first concentration was strong, and the overall distribution of troops was scattered. However, it is unsure whether this concentration came from Juyong Pass or joint action with Bao cities, so it is necessary to remove these large settlements to simulate again. 
Table 1. Rank-Size analyse results of troops.

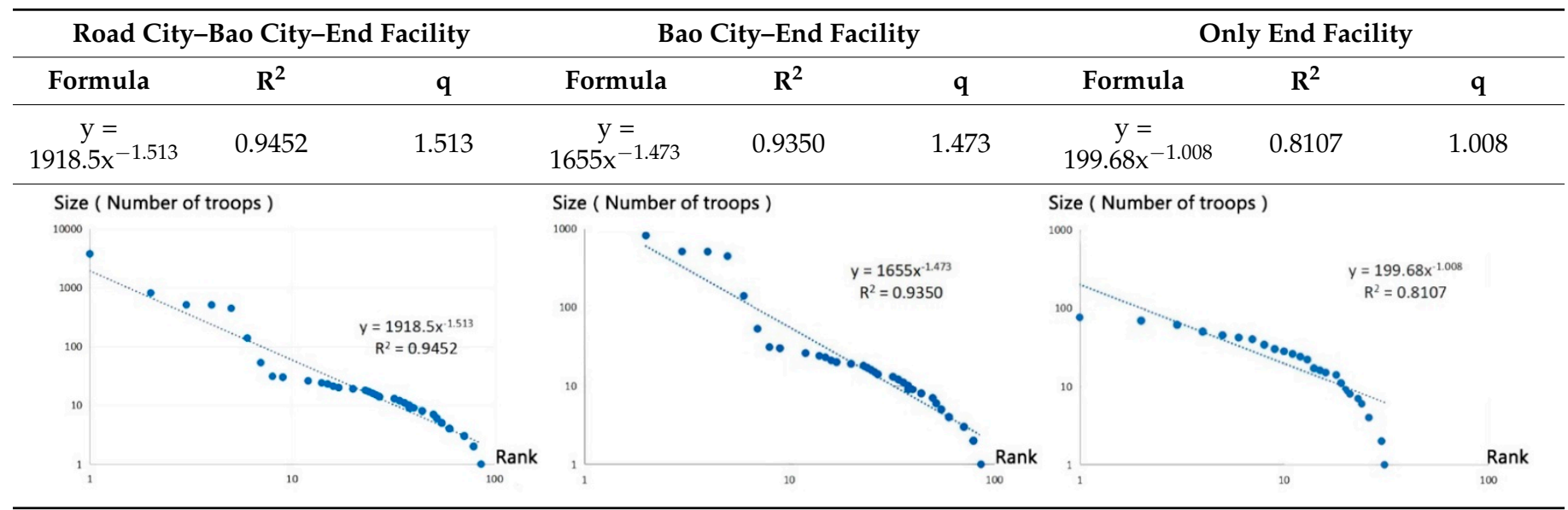

If only the Juyong Pass is removed, $\mathrm{q}=1.473$. Compared to the total settlement $\mathrm{q}=1.513$, that is only a decrease of 0.04 . If Juyong Pass and Bao cities are removed simultaneously, $\mathrm{q}=1.008$, very close to 1 , which represents a balanced distribution. Although Juyong Pass is in the leading position, troop concentration in the Juyong defense area is reflected not only in Juyong Pass but in both the Road cities and Bao cities. From the first scatter plot (Table 1), the gap between the highest point (Juyong Pass) and the secondechelon points (Bao cities) is not as significant as the gap between the Bao cities and the End facilities in the second scatter plot. Moreover, there is no gap in the third scatter plot for all End facilities. Overall, although Juyong Pass had the highest number of troops, the Bao cities, especially in the western part, had a higher concentration and played a significant military role.

\subsection{Clustering of Beacons}

Apart from military settlements and troops, the fortification in charge of information transmission was also a vital military resource. It was mainly divided into a beacon and post. As the Juyong defense area was in a mountainous area, land transportation was very inconvenient, so the transmission of the beacon system was significant. Moreover, the mountains are continuous and the ridges are intertwined into nets, which are favourable conditions for developing the beacon system. However, because beacon sites were mainly on the top of the mountains, they were exposed to long-term weathering, which is why fewer sites are preserved. According to statistics in the Annal of the four towns and three passes and the Annal of Xiguan [22], there were 125 beacon towers in this defense area, belonging to the Juyong Pass and the five-part settlements (Table 2).

Table 2. Distribution of beacons and the number of troops guarding the beacon system.

\begin{tabular}{|c|c|c|c|c|c|c|}
\hline & $\begin{array}{l}\text { Pass } \\
\text { City }\end{array}$ & $\begin{array}{c}\text { Eastern } \\
\text { Part }\end{array}$ & $\begin{array}{c}\text { Western } \\
\text { Part }\end{array}$ & $\begin{array}{c}\text { Middle } \\
\text { Part }\end{array}$ & $\begin{array}{c}\text { Northern } \\
\text { Part }\end{array}$ & $\begin{array}{c}\text { Southern } \\
\text { Part }\end{array}$ \\
\hline Total number of beacons & 12 & 23 & 54 & 12 & 10 & 12 \\
\hline Total number of settlements & 5 & 14 & 60 & 11 & 6 & 12 \\
\hline Total number of troops guarding beacons & 90 & 75 & 146 & 12 & 20 & 12 \\
\hline Average number of beacons per settlement & 2.4 & 1.6 & 0.9 & 1.1 & 1.7 & 1 \\
\hline Average number of troops per beacon & 7.5 & 3.3 & 2.7 & 1 & 2 & 1 \\
\hline
\end{tabular}

As shown in Table 2, the western Road settlements rank first for the number of settlements, the number of beacons and the number of troops for guarding the beacons. The five castles controlled by Juyong Pass rank first in the average number of beacons per settlement and the average number of troops per beacon, which shows that the Juyong Pass controlled the highest density of military resources in the beacon system, and the 
western settlements controlled the highest number of beacon towers. Both were ahead of the rest of the defense area in military messaging ability.

\subsection{Clustering of Weapons}

In addition to the abovementioned physical fortifications, weapons warehouses (armories) and weapons were also critical military resources. There were 12 types of weapons and 23 types of firearms, and five armories: one in Juyong Pass and one in each of the four Bao cities (Changyu, Hengling, Zhenbian, and Baiyangkou) in the west [17]. Among them, the Baiyangkou armory had the largest storage capacity. Overall, the western settlements had most of the weapon resources.

\subsection{Clustering of Wars}

The distribution of the above military resources is closely related to the actual battle defense. In Ming shi lu [24], eight significant battles took place in the Juyong defense area during the Ming Dynasty (Table 3). In addition to attacks on the entire Juyong defense area in 1449 and 1550, four of the other six big battles took place at Baiyangkou in the west and accounted for half of the total, which was consistent with the military settlement and weapon density distribution. It meant that the western part of the Juyong defense area, especially around Baiyangkou, had the most intensive military and weapons, as well as a relatively dense concentration of beacons and troops to meet the frequent military needs in this area. The reason for the frequent attacks on the western settlements is that the Juyong Pass was too tightly guarded and difficult to break through. The minority tribes instead choose to detour to the west and attack Nankou via Baiyangkou (Figure 11). Although Juyong Pass was the most vital pass on this defense zone, the four Bao cities in the western part played a more significant military role.

Table 3. Large-scale campaigns in the Juyong defense area recorded in the Ming Shi Lu.

\begin{tabular}{lll}
\hline Dynasty & Time & Place of War \\
\hline Zhengtong & October 1449 (The Revolution Of TuMu $\left.{ }^{1}\right)$ & Juyong defense area \\
Jingtai & June 1450 & Baiyangkou \\
Zhengde & August 1514 & Baiyangkou \\
Zhengde & August 1516 & Baiyangkou \\
Jiajing & January 1534 & Changping \\
Jiajing & August 1550 (Hundred Days' Change ${ }^{1}$ ) & Juyong defense area \\
Jiajing & July 1552 & Baiyangkou \\
Jiajing & September 1561 & Chadao \\
\hline
\end{tabular}

${ }^{1}$ Two of the most extensive wars of the Ming Dynasty which put most of the Great Wall defenses under threat.

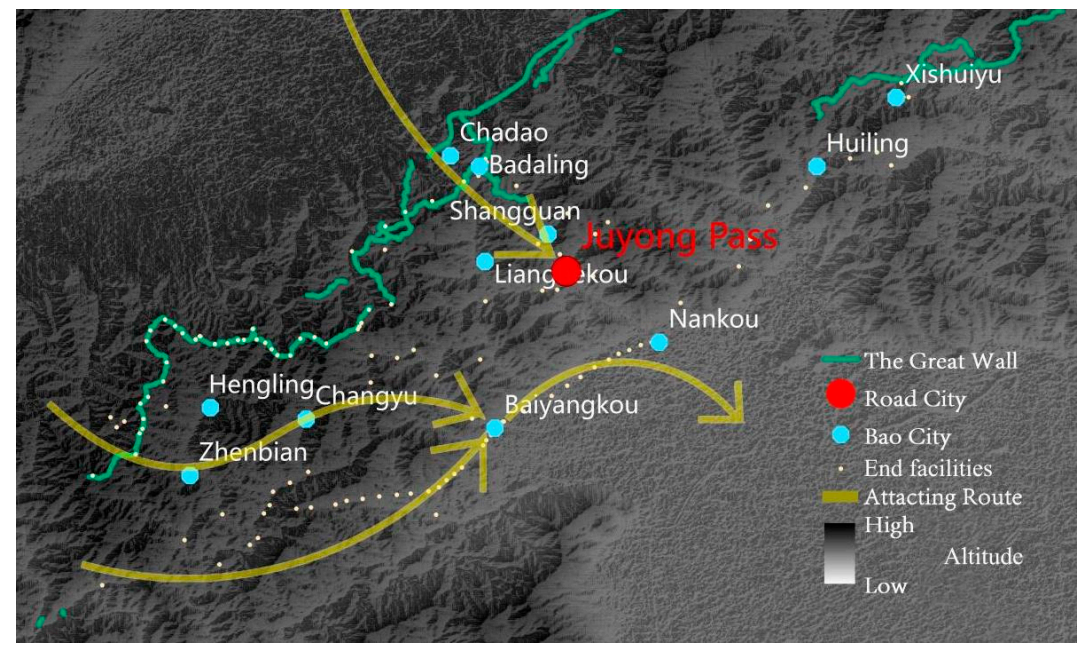

Figure 11. Minority tribes' routes of attack in the Juyong defense area (base map from ASTER GDEM $30 \mathrm{~m}$ elevation data). 


\section{Discussion}

During the Ming Dynasty, when construction of the Great Wall military system was at its peak, most battles occurred in the western part of the Juyong defense area, which had the most number of settlements, troops, beacons, and weapons, whereas Juyong Pass was higher in density of military resources and military rank. Moreover, the western part had enormous military tasks and the most varied fortifications. This conclusion demolished opinions such as "The Great Wall of Beijing is only Juyong and Badaling", or "The Juyong defense zone is same as Juyong Pass". In fact, the Juyong defense area is a complex and substantial military system. The Juyong Pass City and western settlements, especially the four Bao cities (Baiyangkou, Hengling, Zhenbian, and Changyu) are equally important.

\subsection{The Current Conservation Methods for the Great Wall Heritage in the Juyong Defense Area}

The Great Wall spans 11 provinces, all of which are managed by the Regulations on the Protection of the Great Wall [35], which was promulgated by China's State Administration of Cultural Heritage. However, due to the overwhelmingly diverse geographical and social context, this regulation mainly provides only macro-level guidelines. It does not clearly indicate the scope of protection. Specific scope and conservation methods are determined by each regional government and heritage conservation unit, taking into account the characteristics of the Great Wall resources within its jurisdiction. It places the Juyong defense area, although a whole, into to two regions, Beijing and Hebei. Part of the settlements belong to Beijing, but the most resource-rich defense area belongs to Zhangjiakou and Beijing, three districts and two provinces [36].

On the one hand, in the Beijing Great Wall Cultural Belt Protection and Development Plan published by the Beijing Municipal Bureau of Cultural Heritage, the Great Wall resources within Beijing are divided into five zones, including the Juyong-Badaling Cluster (Figure 12). The protection zone is defined according to the principle " $500 \mathrm{~m}$ on both sides of the wall is a non-construction area [and] 500 to $3000 \mathrm{~m}$ is a restricted construction area" [37]. On the other hand, Zhangjiakou is part of Hebei Province and implements the Hebei Ming Great Wall Protection Plan [38], issued by the Hebei Provincial Cultural Relics Bureau. The Great Wall heritage resources in Hebei Province are continuously distributed on the eastern, northern, and southwestern sides, forming three clusters. The Great Wall sites under the jurisdiction of Zhenbian and Hengling on the western side of the defense zone exist alone and are not planned as a whole with the other parts (Figure 12). When delineating the scope of protection, the Great Wall in the mountainous areas is in principle bounded by the bottom of slopes and valleys. Those in gently sloping areas are protected as far as possible to preserve the integrity of the cultural landscape. In addition, for the other single sites, the outer edge of the building wall foundation at the baseline has been expanded by $50 \mathrm{~m}$ to create a protection scope. Although the western part of the Juyong defense area repeatedly shuttles between Beijing and Hebei Province, the two regions have not adopted the same conservation planning strategy. As a result, neither has provided holistic protection or synergistic management in the border zone.

\subsection{The Current State of the Great Wall Heritage Conservation in the Juyong Defense Area}

Today, 64 Great Wall heritage relics are preserved at different political levels within the Juyong defense area (Appendix B): 2 national, 3 municipal, 9 district, 7 county, and 43 at no level $[39,40]$. The proportion of cultural heritage units is only $32.8 \%$. Although there are many sites in this defense area, only a tiny percentage of the Great Wall is in good condition. Of these 64 sites, 34 are in the former westernest Road defense area, and only 10 have established protection units. This accounts for only $29.4 \%$ of the total, which is lower than the region's average; thus, the westernest Road settlement's actual exploitation, which occupies most of the Great Wall resources in the Juyong defense area, is inadequate and far inferior to Juyong Pass. The conservation of the Great Wall heritage in the Juyong defense area is polarised, while the development of infrastructure and tourism resources is highly uneven. 

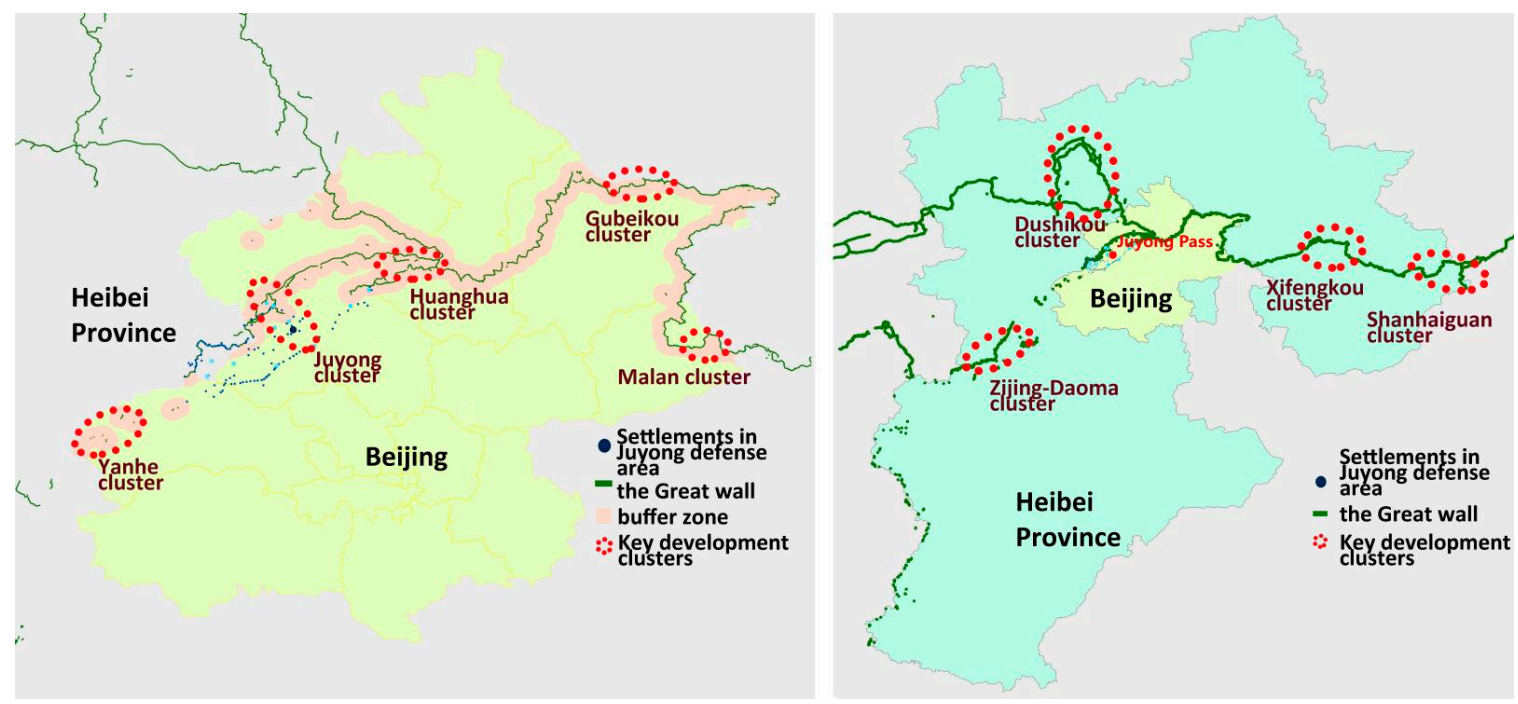

Figure 12. On the left: distribution of the Great Wall heritage resources in Beijing and the planning of five core development clusters. On the right: distribution of the Great Wall heritage resources in Heibei Province.

Badaling and Juyong Pass are majestic and in the heart of the defense zone, where tourism development progresses rapidly. At the end of the last century, the Beijing Municipal Bureau of Cultural Heritage set up the Badaling Special Zone to manage the conservation and preservation of Badaling and Juyong Pass. Due to the long period of warfare in the Juyong defense area before the founding of New China, both were severely damaged. Most of the Great Wall we currently see in this scenic area has been rebuilt over the last 30 years (Figure 13). To a certain extent, the authenticity and integrity of its heritage have been damaged for the sake of construction of tourist facilities [3]. However, with the development of tourism in Beijing, the two castles also face insufficient carrying capacity and over-exploitation of resources. In contrast, the current state of the western settlements, which also possesses profound historical value, is very different. Only one Great Wall hiking trail has been set up in this area, and the rest of the site has no large-scale development of Great Wall heritage resources. Although small-scale repairs have been organized by various district-level cultural preservation units since 2000, they have not had the desired social impact. The wall itself in this area suffers from severe weathering, crumbling, human-made damage, and a lack of routine supervision and maintenance. For example, during the Ching Ming holiday (4 April 2021), a traditional Chinese festival, the Badaling Great Wall received more than 40,000 visitors in a single day [41]; yet, the Western Great Wall site, which also has excellent Great Wall resources, was less visited (Figure 13). Therefore, it is necessary to develop other Great Wall scenic areas around the capital to relieve the tourism pressure on the Juyong Pass and Badaling.
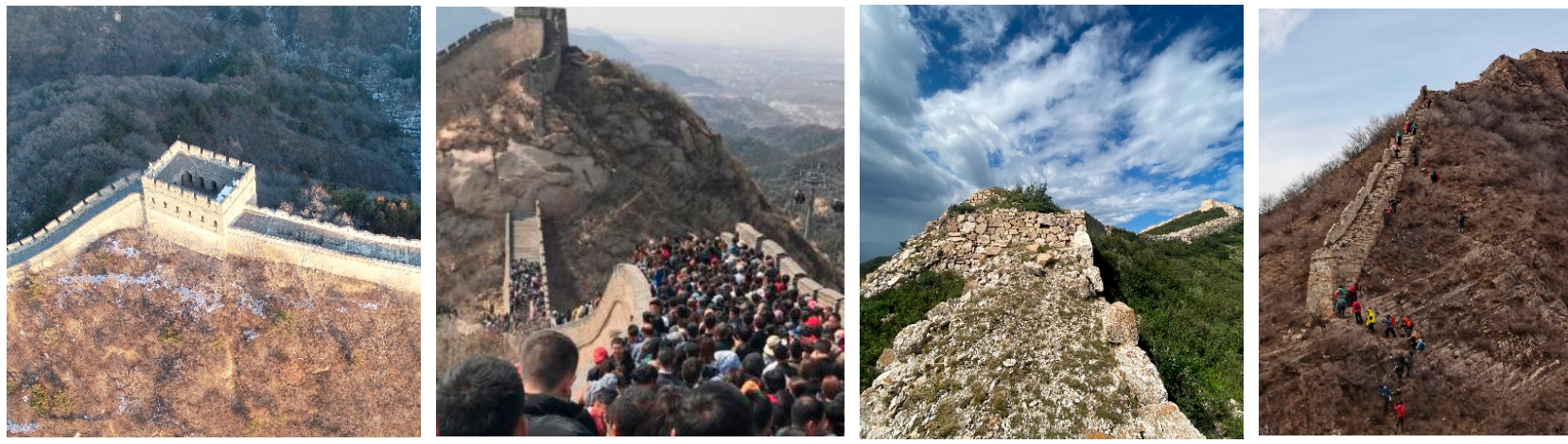

Figure 13. From left: the status of the Great Wall at Badaling and the crowed scenic spot; the Great Wall in Changyu town on 5 April 2021; the status of the Great Wall in Zhenbian town and the peopleless scenic spot. 


\subsection{Suggestions for Protecting Great Wall Heritage in the Juyong Defense Area}

The current management method of the Great Wall divides protective departments by the administrative territory of the heritage [42]. Different policies for daily management and restoration make it difficult to follow the large Pass city's role in history, which seriously fragments the development of the western settlements' resources. Although the Great Wall around Hengling, Changyu, and Zhenbian are continuous, Hengling and Zhenbian follow different conservation plans designed by Hebei Province and are restricted by administrative divisions. Moreover, they cannot become a core cluster of the Great Wall heritage in Hebei or Beijing. It is necessary to clarify the actual scope of the protection of the Juyong defense area to develop a unified and coordinated conservation strategy, and to promote collaboration between the Zhangjiakou and Beijing heritage conservation authorities. Integrating Great Wall heritage in the western part of the Juyong defense area will help to form the Juyong western heritage and tourism zone torelieve tourism pressure in the Beijing Great Wall Cultural Belt.

\subsection{Integral Protection of the Great Wall Heritage of Other Large Pass Cities}

In addition to the Juyong Pass defense area, there were also the Yanmen Pass and Shanhai Pass defense areas and the Jiayu Pass defense area in ancient China. Due to its pivotal geographical position, each of these Pass cities are not isolated but linked to or governed by a much larger territory in contrast to the usual large castles along the Great Wall. For example, the Juyong Pass covers an area of $0.6 \mathrm{~km}^{2}$, while the Juyong defense area covers nearly $800 \mathrm{~km}^{2}$; the Yanmen Pass also only covers about $0.5 \mathrm{~km}^{2}$ (Figure 14), and the ancient Yanmen Pass defense area reached about $200 \mathrm{~km}^{2}$ [43]. Therefore, the large Pass city defense area may be hundreds of times larger than the area of a single castle, and these areas also retain a rich cultural heritage to be developed. However, the current approach to managing the Great Wall's heritage is influenced by the fragmentation of administrative boundaries, and government efforts to protect small cultural heritage sites in isolation. It is necessary to sort out the ancient military system of these large Pass cities and clarify the boundaries of their defense areas to provide sufficient theoretical support for their holistic conservation. Does the protection of the Great Wall large-scale Pass city respect the actual military scope of the Great Wall military system? Is the integral protection strategy implemented for all military settlement heritage in the same defense area? These are the two critical issues underlying the need for sustainable protection and development of the cultural heritage resources of the Pass city in the Great Wall system.

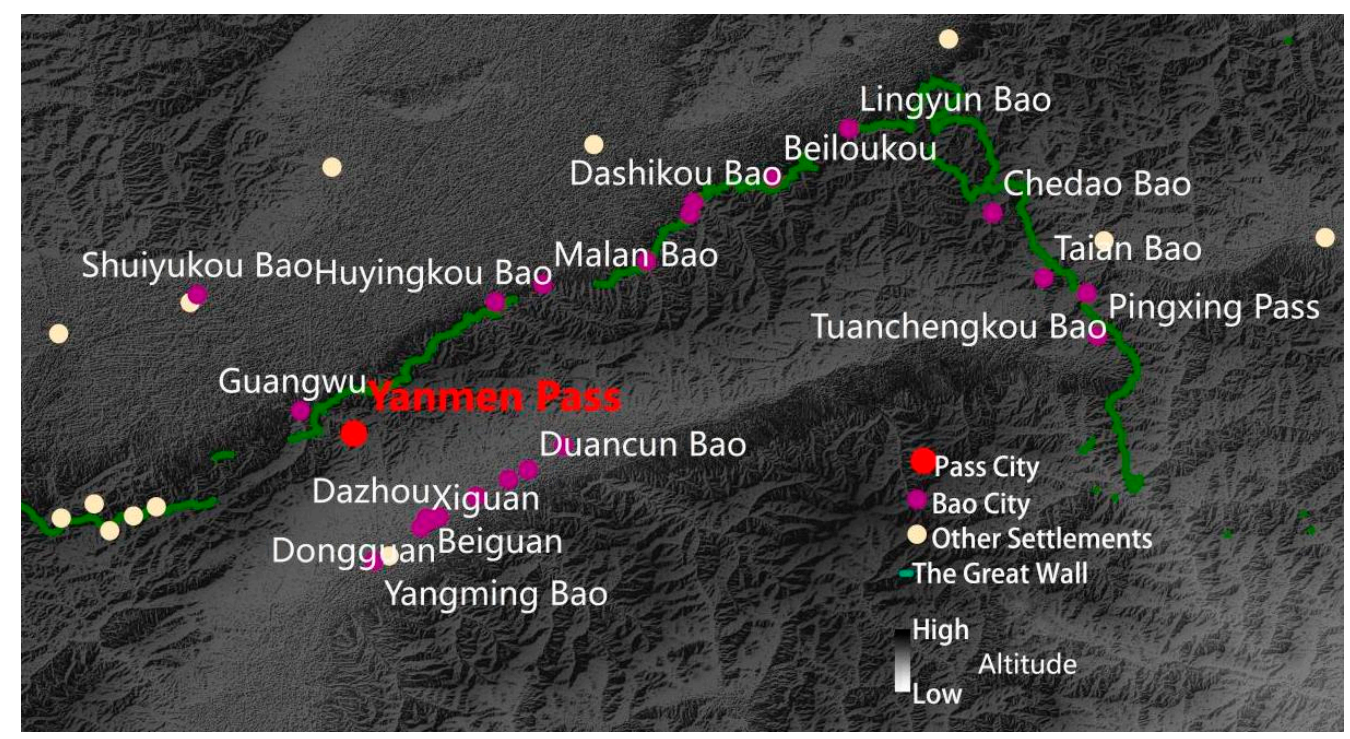

Figure 14. Yanmen defense area military settlement distribution (base map from ASTER GDEM-30 m elevation data). 


\section{Conclusions}

Taking as an example the most influential and representative castle, the Juyong Pass Great Wall, this study sought to solve the limitations of understanding to conserve the large-scale Pass city. The geographical scope and military function of the Juyong Pass and Juyong defense area are different. During the Ming Dynasty, when the Great Wall's military system was at its most complete, the western part of this defense area was on an equal footing with the Juyong Castle for settlement, garrison, beacon, and weapon distribution. It occupied more than half of the entire area's military resources and had significant historical and military value. In modern times, more than half of the Great Wall heritage resources are also located in the west, but the state of their heritage preservation is far behind that of Juyong Pass. It is necessary to increase the protection and development of the western Great Wall settlement in the Juyong defense area and build a complete Great Wall cultural heritage zone to integrate resources to put an end to the lack of synchronization in the development of resources by different administrative divisions. It would also have value for constructing the historical and military systems of other large passes along the Great Wall, excavating heritage values, delineating conservation areas, and promoting sustainable, holistic development.

Author Contributions: Conceptualization, Y.Z.; methodology, J.Z.; software, S.L.; validation, L.T., S.L., and J.Z.; formal analysis, J.Z.; investigation, S.L.; resources, J.Z.; data curation, S.L.; writingoriginal draft preparation, S.L.; writing-review and editing, J.Z. and Y.Z.; visualization, J.Z.; supervision, Y.Z.; project administration, Y.Z.; funding acquisition, L.T. All authors have read and agreed to the published version of the manuscript.

Funding: This research was supported by the National Natural Science Foundation of China (52078324) and Major Research on Philosophy and Social Sciences of the Ministry of Education of China (19JZD056).

Institutional Review Board Statement: Not applicable.

Informed Consent Statement: Not applicable.

Data Availability Statement: Data can be provided upon request from the corresponding author.

Acknowledgments: Thanks to the Liuhe Studio of the School of Architecture of Tianjin University for providing information on the whole line of settlements of the Ming Great Wall.

Conflicts of Interest: The authors declare no conflict of interest.

\section{Appendix A}

Table A1. Historical and geographical data of Juyong Pass defense area covered in this paper [22-24].

\begin{tabular}{|c|c|c|c|c|c|c|c|c|}
\hline Name & Level & Location & $\begin{array}{c}\text { Number of } \\
\text { Troops }\end{array}$ & $\begin{array}{l}\text { Elevation } \\
\quad(\mathrm{m})\end{array}$ & $\begin{array}{c}\text { Slope } \\
\text { (Degree) }\end{array}$ & $\begin{array}{c}\text { Slope } \\
\text { Direction } \\
\text { (Degree) }\end{array}$ & Latitude & Longitude \\
\hline Juyong Pass & Road city & Pass city & 3750 & 264 & 5.32 & 79.7 & 40.29 & 116.07 \\
\hline Shangguan & Bao city & Pass city & 30 & 354 & 1.97 & 165.96 & 40.31 & 116.06 \\
\hline Nankou & Bao city & Pass city & 0 & 112 & 0.95 & 0 & 40.22 & 0 \\
\hline Chadao & Bao city & Pass city & 0 & 592 & 2.43 & 258.69 & 40.36 & 115.99 \\
\hline Badaling & Bao city & Pass city & 53 & 692 & 15.9 & 249.44 & 40.36 & 116.01 \\
\hline Xishuiyu & Bao city & East & 20 & 369 & 9.97 & 84.56 & 40.41 & 116.31 \\
\hline Huilingkou & Bao city & East & 139 & 262 & 3.52 & 118.3 & 40.35 & 116.24 \\
\hline Zhuishikou & End facility & East & 14 & 198 & 10.16 & 178.67 & 40.33 & 116.21 \\
\hline Zhuangdaokou & End facility & East & 14 & 354 & 8.06 & 42.61 & 40.41 & 116.31 \\
\hline Zaoyuanzhuang & End facility & East & 2 & 452 & 12.96 & 137.94 & 40.33 & 116.21 \\
\hline Yaoziyu & End facility & East & 30 & 344 & 11.33 & 315 & 40.41 & 116.31 \\
\hline Yangmayu & End facility & East & 3 & 321 & 10.29 & 238.13 & 40.29 & 116.19 \\
\hline Yanmenkou & End facility & East & 4 & 212 & 3.84 & 172.87 & 40.31 & 116.19 \\
\hline Xianzhuangkou & End facility & East & 31 & 224 & 7.57 & 57.8 & 40.33 & 116.21 \\
\hline Shihudaokou & End facility & East & 5 & 429 & 18.07 & 61.8 & 40.41 & 116.31 \\
\hline Shichengyu & End facility & East & 9 & 298 & 6.93 & 202.17 & 40.33 & 116.21 \\
\hline Menjiayukou & End facility & East & 4 & 379 & 5.52 & 277.43 & 40.33 & 116.21 \\
\hline Huyukou & End facility & East & 11 & 211 & 9.57 & 171.47 & 40.29 & 116.19 \\
\hline Deshengkou & End facility & East & 24 & 148 & 4.39 & 347.47 & 40.29 & 116.19 \\
\hline Changshuiyu & End facility & South & 6 & 97 & 0.34 & 45 & 40.21 & 116.01 \\
\hline
\end{tabular}


Table A1. Cont.

\begin{tabular}{|c|c|c|c|c|c|c|c|c|}
\hline Name & Level & Location & $\begin{array}{c}\text { Number of } \\
\text { Troops }\end{array}$ & $\begin{array}{l}\text { Elevation } \\
\text { (m) }\end{array}$ & $\begin{array}{c}\text { Slope } \\
\text { (Degree) }\end{array}$ & $\begin{array}{c}\text { Slope } \\
\text { Direction } \\
\text { (Degree) }\end{array}$ & Latitude & Longitude \\
\hline Anmoyukou & End facility & South & 3 & 123 & 1.82 & 113.2 & 40.21 & 116.01 \\
\hline Xiaoyukou & End facility & South & 4 & 112 & 2.78 & 329.04 & 40.21 & 116.01 \\
\hline Xiaokujiang & End facility & South & 8 & 218 & 1.69 & 8.13 & 40.21 & 116.01 \\
\hline Tangyukou & End facility & South & 8 & 106 & 1.72 & 213.69 & 40.21 & 116.01 \\
\hline Tanyukou & End facility & South & 3 & 95 & 1.69 & 135 & 40.21 & 116.01 \\
\hline Sulinkou & End facility & South & 15 & 136 & 4.43 & 126.25 & 40.21 & 116.01 \\
\hline Shuiyukou & End facility & South & 3 & 107 & 2.13 & 206.57 & 40.21 & 116.01 \\
\hline Lujiaowankou & End facility & South & 13 & 414 & 12.71 & 4.24 & 40.36 & 116.01 \\
\hline Heizhejiankou & End facility & South & 8 & 179 & 2.13 & 63.43 & 40.21 & 116.01 \\
\hline Dayukou & End facility & South & 4 & 112 & 1.69 & 188.13 & 40.21 & 116.01 \\
\hline Dakujiangkou & End facility & South & 4 & 221 & 1.69 & 45 & 40.21 & 116.01 \\
\hline Yujiachong & End facility & North & 10 & 1105 & 6.75 & 219.29 & 40.3 & 115.95 \\
\hline Shixiayu & End facility & North & 26 & 669 & 1.97 & 255.96 & 40.3 & 115.95 \\
\hline Miziyu & End facility & North & 26 & 665 & 21.51 & 283.45 & 40.3 & 115.95 \\
\hline Huamuliangkou & End facility & North & 14 & 798 & 8.11 & 322.13 & 40.3 & 115.95 \\
\hline Huajiayaokou & End facility & North & 19 & 735 & 6.85 & 213.69 & 40.3 & 115.95 \\
\hline Lianghekou & Bao city & Center & 17 & 427 & 7.14 & 183.81 & 40.36 & 116.01 \\
\hline Xiaolingkou & End facility & Center & 4 & 237 & 10.48 & 67.48 & 40.36 & 116.01 \\
\hline Xiangzhakou & End facility & Center & 3 & 253 & 15.91 & 296.94 & 40.36 & 116.01 \\
\hline Wangguakou & End facility & Center & 0 & 840 & 13.89 & 147.38 & 40.36 & 116.01 \\
\hline Shuangquankou & End facility & Center & 5 & 715 & 6.72 & 135 & 40.36 & 116.01 \\
\hline Shifosi & End facility & Center & 12 & 684 & 5.26 & 5.19 & 40.36 & 116.01 \\
\hline Shifengshan & End facility & Center & 9 & 353 & 8.58 & 173.66 & 40.36 & 116.01 \\
\hline WestQinglongqiao & End facility & Center & 4 & 750 & 9.65 & 149.04 & 40.36 & 116.01 \\
\hline East Qinglongqiao & End facility & Center & 7 & 603 & 4.82 & 69.78 & 40.36 & 116.01 \\
\hline Huangtuling & End facility & Center & 4 & 704 & 11.8 & 208.61 & 40.36 & 116.01 \\
\hline Heidougu & End facility & Center & 0 & 681 & 12.96 & 328.32 & 40.36 & 116.01 \\
\hline Hebaikou & End facility & Center & 3 & 442 & 13.77 & 125.31 & 40.36 & 116.01 \\
\hline Chenyouliang & End facility & Center & 3 & 549 & 12.81 & 193.78 & 40.36 & 116.01 \\
\hline Zhenbian & Bao city & West & 510 & 764 & 3.84 & 60.26 & 40.36 & 116.01 \\
\hline Changyu & Bao city & West & 445 & 834 & 2.16 & 96.34 & 40.15 & 115.93 \\
\hline Baiyangkou & Bao city & West & 814 & 214 & 0.75 & 18.43 & 40.21 & 116.01 \\
\hline Hengling & Bao city & West & 508 & 871 & 2.05 & 215.54 & 40.36 & 116.01 \\
\hline Changchengkou & End facility & West & 4 & 667 & 6.2 & 274.4 & 40.14 & 115.9 \\
\hline Zhazigou & End facility & West & 0 & 708 & 6.65 & 270 & 40.36 & 116.01 \\
\hline Yingwokou & End facility & West & 0 & 1147 & 4.39 & 167.47 & 40.36 & 116.01 \\
\hline Yingliangdong & End facility & West & 0 & 1119 & 9.19 & 124.51 & 40.36 & 116.01 \\
\hline Xiongeryu & End facility & West & 16 & 1035 & 5.99 & 186.84 & 40.36 & 116.01 \\
\hline Xinkaikou & End facility & West & 0 & 580 & 9.47 & 2.86 & 40.15 & 115.93 \\
\hline Xiaoshuiyu & End facility & West & 8 & 333 & 10.86 & 124.38 & 40.36 & 116.01 \\
\hline Xiaoshankou & End facility & West & 0 & 1074 & 5.39 & 225 & 40.36 & 116.01 \\
\hline Xiaolingyu & End facility & West & 2 & 688 & 2.72 & 105.26 & 40.15 & 115.93 \\
\hline Xishanankou & End facility & West & 0 & 509 & 17.97 & 154.09 & 40.36 & 116.01 \\
\hline Xiliangshuiquan & End facility & West & 0 & 1053 & 4.79 & 185.71 & 40.36 & 116.01 \\
\hline Xihuangluyuan & End facility & West & 0 & 1149 & 8.05 & 135 & 40.36 & 116.01 \\
\hline Xihetaochong & End facility & West & 0 & 1023 & 25.57 & 277 & 40.36 & 116.01 \\
\hline Xibeijie & End facility & West & 13 & 1294 & 9.23 & 1.47 & 40.36 & 116.01 \\
\hline Wozitou & End facility & West & 0 & 598 & 3.58 & 93.81 & 40.36 & 116.01 \\
\hline Tulingkou & End facility & West & 5 & 1068 & 7.92 & 171.38 & 40.36 & 116.01 \\
\hline Tiaoshaokou & End facility & West & 14 & 314 & 6.63 & 165.47 & 40.36 & 116.01 \\
\hline Songshuding & End facility & West & 0 & 1262 & 15.44 & 303.93 & 40.36 & 116.01 \\
\hline Songhupian & End facility & West & 8 & 352 & 8.3 & 91.64 & 40.36 & 116.01 \\
\hline Sierliang & End facility & West & 0 & 1073 & 10.77 & 61.19 & 40.36 & 116.01 \\
\hline Shuiyutai & End facility & West & 6 & 242 & 11.95 & 147.88 & 40.36 & 116.01 \\
\hline Shuijiankou & End facility & West & 30 & 359 & 5.88 & 158.63 & 40.15 & 115.93 \\
\hline Shuangshigou & End facility & West & 0 & 241 & 2.46 & 119.05 & 40.36 & 116.01 \\
\hline Shuzikou & End facility & West & 2 & 366 & 2.13 & 206.57 & 40.12 & 115.86 \\
\hline Shijiankou & End facility & West & 9 & 303 & 5.13 & 158.2 & 40.36 & 116.01 \\
\hline Shibanchong & End facility & West & 0 & 567 & 16.42 & 326.53 & 40.36 & 116.01 \\
\hline Shengxianyu & End facility & West & 7 & 330 & 8.72 & 137.2 & 40.36 & 116.01 \\
\hline Shangchangyu & End facility & West & 8 & 845 & 7.18 & 214.22 & 40.15 & 115.93 \\
\hline Shalinger & End facility & West & 0 & 1238 & 13.33 & 320.71 & 40.36 & 116.01 \\
\hline Sanmugou & End facility & West & 0 & 1096 & 14.48 & 10.22 & 40.36 & 116.01 \\
\hline Ruanzaoding & End facility & West & 0 & 1039 & 14.26 & 180.94 & 40.36 & 116.01 \\
\hline Qingquankou & End facility & West & 14 & 239 & 3.65 & 78.69 & 40.36 & 116.01 \\
\hline Qianshijian & End facility & West & 4 & 691 & 9.39 & 139.09 & 40.15 & 115.93 \\
\hline Niuxiyukou & End facility & West & 20 & 1131 & 7.57 & 147.8 & 40.36 & 116.01 \\
\hline Niulagou & End facility & West & 0 & 953 & 13.13 & 0 & 40.36 & 116.01 \\
\hline Nantangeryan & End facility & West & 0 & 1312 & 20.56 & 323.13 & 40.36 & 116.01 \\
\hline Nanshiyang & End facility & West & 2 & 597 & 3.32 & 158.96 & 40.12 & 115.86 \\
\hline Miaoerliang & End facility & West & 0 & 1234 & 15.68 & 185.96 & 40.36 & 116.01 \\
\hline Liushugou & End facility & West & 0 & 644 & 5.13 & 291.8 & 40.14 & 115.9 \\
\hline Liushigang & End facility & West & 5 & 505 & 5.73 & 184.76 & 40.15 & 115.93 \\
\hline Lishikou & End facility & West & 23 & 1342 & 6.06 & 11.31 & 40.36 & 116.01 \\
\hline Kulongshan & End facility & West & 0 & 1024 & 30.35 & 196.11 & 40.36 & 116.01 \\
\hline Jingergu & End facility & West & 0 & 1174 & 13.64 & 195.95 & 40.36 & 116.01 \\
\hline Jiaoziding & End facility & West & 0 & 1212 & 8.39 & 227.29 & 40.36 & 116.01 \\
\hline Liangjialiang & End facility & West & 0 & 1087 & 22.19 & 304.18 & 40.36 & 116.01 \\
\hline Huoshiling & End facility & West & 9 & 1032 & 13.62 & 220.82 & 40.36 & 116.01 \\
\hline Huiguankou & End facility & West & 3 & 497 & 6.34 & 102.99 & 40.15 & 115.93 \\
\hline
\end{tabular}


Table A1. Cont.

\begin{tabular}{|c|c|c|c|c|c|c|c|c|}
\hline Name & Level & Location & $\begin{array}{l}\text { Number of } \\
\text { Troops }\end{array}$ & $\begin{array}{l}\text { Elevation } \\
\text { (m) }\end{array}$ & $\begin{array}{c}\text { Slope } \\
\text { (Degree) }\end{array}$ & $\begin{array}{c}\text { Slope } \\
\text { Direction } \\
\text { (Degree) }\end{array}$ & Latitude & Longitude \\
\hline Huangshiya & End facility & West & 0 & 1165 & 16.51 & 207.65 & 40.36 & 116.01 \\
\hline Heichonggu & End facility & West & 0 & 1217 & 11.18 & 304.7 & 40.36 & 116.01 \\
\hline Guizhian & End facility & West & 0 & 1481 & 15.13 & 236.31 & 40.36 & 116.01 \\
\hline Gaoyakou & End facility & West & 21 & 244 & 10.77 & 151.19 & 40.14 & 115.98 \\
\hline Fenshuiling & End facility & West & 0 & 1119 & 17.23 & 239.3 & 40.36 & 116.01 \\
\hline Fangliangkou & End facility & West & 10 & 598 & 1.69 & 188.13 & 40.12 & 115.86 \\
\hline Dongjiakou & End facility & West & 1 & 936 & 11.73 & 51.52 & 40.14 & 115.9 \\
\hline Dongliangshuiquan & End facility & West & 0 & 1076 & 14.78 & 291.3 & 40.36 & 116.01 \\
\hline Donghuangluyuan & End facility & West & 0 & 1145 & 9.02 & 336.8 & 40.36 & 116.01 \\
\hline Donghetaochong & End facility & West & 0 & 1032 & 13.09 & 255.47 & 40.36 & 116.01 \\
\hline Dongbeijie & End facility & West & 19 & 1024 & 18.64 & 115.62 & 40.36 & 116.01 \\
\hline Daofanchong & End facility & West & 12 & 962 & 15.38 & 270 & 40.36 & 116.01 \\
\hline Dashuiyukou & End facility & West & 19 & 328 & 7.51 & 108.43 & 40.36 & 116.01 \\
\hline Dashigoukou & End facility & West & 0 & 1022 & 20.04 & 13.88 & 40.36 & 116.01 \\
\hline Chetougou & End facility & West & 0 & 1270 & 21.84 & 159.3 & 40.36 & 116.01 \\
\hline Changyuxikou & End facility & West & 4 & 581 & 5.99 & 96.84 & 40.12 & 115.86 \\
\hline Changyukou & End facility & West & 11 & 698 & 2.13 & 206.57 & 40.15 & 115.93 \\
\hline Chayatuo & End facility & West & 0 & 1334 & 26.27 & 348.31 & 40.36 & 116.01 \\
\hline Beitangeryan & End facility & West & 0 & 1311 & 8.81 & 216.25 & 40.36 & 116.01 \\
\hline Beishiyangkou & End facility & West & 2 & 665 & 5.88 & 68.63 & 40.12 & 115.86 \\
\hline Beigangkou & End facility & West & 6 & 1289 & 9.3 & 277.31 & 40.36 & 116.01 \\
\hline Banglukou & End facility & West & 2 & 667 & 6.67 & 184.09 & 40.12 & 115.86 \\
\hline Baiyukou & End facility & West & 18 & 232 & 1.72 & 56.31 & 40.36 & 116.01 \\
\hline Baiyazikou & End facility & West & 20 & 1092 & 13.04 & 120.26 & 40.36 & 116.01 \\
\hline Baipubukou & End facility & West & 2 & 769 & 9.75 & 157.17 & 40.14 & 115.9 \\
\hline Aoyukou & End facility & West & 5 & 416 & 6.85 & 56.31 & 40.15 & 115.93 \\
\hline
\end{tabular}

\section{Appendix B}

Table A2. The existing Great Wall cultural relic protection units in Juyong defense area [39,40].

\begin{tabular}{|c|c|c|c|c|c|}
\hline Name & Location & Type & Level & Condition & $\begin{array}{c}\text { Region in Ming } \\
\text { Dynasty }\end{array}$ \\
\hline Hengling & Huailai, Hebei & Castle & Municipality & Poor & Western part \\
\hline Zhenbian & Huailai, Hebei & Castle & Municipality & General & Western part \\
\hline Yuanchengling & Huailai, Hebei & Castle & District & Poor & Western part \\
\hline Shuitou Water Pass & Huailai, Hebei & Water ass & No & Poor & Western part \\
\hline Yangerling & Huailai, Hebei & City wall & No & Poor & Western part \\
\hline Jiaozhuang & Huailai, Hebei & City wall & No & Poor & Western part \\
\hline West Dongwan & Huailai, Hebei & City wall & No & Poor & Western part \\
\hline East Dongwan & Huailai, Hebei & City wall & No & Poor & Western part \\
\hline Large Shankou & Huailai, Hebei & City wall & No & Poor & Western part \\
\hline Small Shankou & Huailai, Hebei & City wall & No & Poor & Western part \\
\hline Shibajia & Huailai, Hebei & City wall & No & Poor & Western part \\
\hline Southeast Yaocun & Huailai, Hebei & City wall & No & Poor & Western part \\
\hline Southwest Yaocun & Huailai, Hebei & City wall & No & Poor & Western part \\
\hline West Huayuan & Huailai, Hebei & Beacon & No & Good & Western part \\
\hline East Huayuan & Huailai, Hebei & Beacon & No & Good & Western part \\
\hline Taishizhuang & Huailai, Hebei & Beacon & No & General & Western part \\
\hline Jimingyi & Huailai, Hebei & Beacon & No & General & Northern part \\
\hline West Quanshui & Huailai, Hebei & Beacon & No & Good & Northern part \\
\hline Xiabali & Huailai, Hebei & Beacon & No & Poor & Northern part \\
\hline West Bali & Huailai, Hebei & Beacon & No & Poor & Northern part \\
\hline Xiaoyingfeng & Huailai, Hebei & Beacon & No & Good & Northern part \\
\hline Yanhe City & Mentougou, Beijing & Castle & Municipality & General & Western part \\
\hline Fangliangkou & Mentougou, Beijing & Castle & No & General & Western part \\
\hline Xiaolongmen & Mentougou, Beijing & Beacon & No & General & Western part \\
\hline Liyuanling & Mentougou, Beijing & Beacon & No & General & Western part \\
\hline Hongshuikou & Mentougou, Beijing & Beacon & No & General & Western part \\
\hline Qizuoliang & Mentougou, Beijing & Beacon & No & General & Western part \\
\hline Baiyukou & Mentougou, Beijing & Castle & No & General & Western part \\
\hline Dahanling & Mentougou, Beijing & Castle & District & Good & Western part \\
\hline Fengkouan & Mentougou, Beijing & Castle & District & Good & Western part \\
\hline Zhaitang & Mentougou, Beijing & Castle & No & Good & Western part \\
\hline Hongshuikou & Mentougou, Beijing & Kiln & No & General & Western part \\
\hline Baiyu & Mentougou, Beijing & Kiln & District & General & Western part \\
\hline Wayaocun & Mentougou, Beijing & Kiln & No & Poor & Western part \\
\hline Wanfotang & Mentougou, Beijing & Temple & No & General & Western part \\
\hline Zhenwu Temple & Mentougou, Beijing & Temple and stone tablet & No & Poor & Western part \\
\hline Laoyugou & Changping, Beijing & City wall & District & General & Western part \\
\hline Juyongguan & Changping, Beijing & $\begin{array}{l}\text { Castle, temple, and } \\
\text { stone tablet }\end{array}$ & Nation & Good & Pass city \\
\hline Shangguan & Changping, Beijing & City wall & District & Poor & Pass city \\
\hline Nankou & Changping, Beijing & City wall & District & Poor & Pass city \\
\hline Changyu & Changping, Beijing & Castle & District & Good & Western part \\
\hline Baiyangkou & Changping, Beijing & City wall & District & General & Western part \\
\hline
\end{tabular}


Table A2. Cont.

\begin{tabular}{|c|c|c|c|c|c|}
\hline Name & Location & Type & Level & Condition & $\begin{array}{c}\text { Region in Ming } \\
\text { Dynasty }\end{array}$ \\
\hline Laojuntang & Changping, Beijing & City wall & No & Poor & Eastern part \\
\hline Huilingkou & Changping, Beijing & City wall & No & Poor & Eastern part \\
\hline Xianzhuangkou & Changping, Beijing & City wall & No & General & Eastern part \\
\hline Zhuishikou & Changping, Beijing & City wall & No & General & Eastern part \\
\hline Yanzikou & Changping, Beijing & City wall & No & General & Eastern part \\
\hline Deshengkou & Changping, Beijing & City wall & No & General & Eastern part \\
\hline Xishankou & Changping, Beijing & City wall & No & General & Eastern part \\
\hline Zhazikou & Changping, Beijing & City wall & No & General & Eastern part \\
\hline Badaling & Yanqing, Beijing & $\begin{array}{l}\text { Castle, temple, and } \\
\text { stone tablet }\end{array}$ & Nation & Good & Pass city \\
\hline Shifosi & Yanqing, Beijing & $\begin{array}{l}\text { Temple, stone tablet, } \\
\text { and beacon }\end{array}$ & County & Good & Middle part \\
\hline Wangjing Stone & Yanqing, Beijing & Stone tablet & County & Good & Northern part \\
\hline Qingshuihe & Yanqing, Beijing & Stone tablet & County & Good & Northern part \\
\hline Donggou & Yanqing, Beijing & Kiln & No & General & Northern part \\
\hline Shixiayao & Yanqing, Beijing & Kiln & No & General & Northern part \\
\hline Xiaozhangjiakou & Yanqing, Beijing & Stone tablet & No & General & Northern part \\
\hline Lipaocun & Yanqing, Beijing & Beacon & No & Poor & Northern part \\
\hline Waipaocun & Yanqing, Beijing & Beacon & No & Poor & Northern part \\
\hline Liugou & Yanqing, Beijing & Castle and temple & County & General & Eastern part \\
\hline Yulin & Yanqing, Beijing & $\begin{array}{l}\text { Castle, temple, and } \\
\text { stone tablet }\end{array}$ & County & General & Northern part \\
\hline Maying & Yanqing, Beijing & Castle & County & General & Northern part \\
\hline Dayingcun & Yanqing, Beijing & Beacon & County & Good & Northern part \\
\hline Guanyinge & Yanqing, Beijing & Temple & No & General & Northern part \\
\hline
\end{tabular}

\section{References}

1. UNESCO. The Great Wall. Available online: http://whc.unesco.org/en/list/438 (accessed on 1 April 2021).

2. ICOMOS. Available online: https://www.icomos.org/en/the-researcher-s-corner/thematic-bibliographies/5831-cultural-routesa-bibliography (accessed on 8 May 2021).

3. Yu, K.; Xi, X.; Li, D.; Li, H.; Liu, K. On the construction of the national linear culture heritage network in China. Hum. Geogr. 2009, $3,11-16,116$.

4. Li, Y.; Zhang, Y.; Li, Z.; Xu, L. Holistic Protection Strategy of the Great Wall Defence System. Chin. Cult. Herit. 2018, 3, 48-54.

5. National Culture Heritage Administration. The Great Wall Protection Master Plan. Available online: http://www.ncha.gov.cn/ art/2019/1/28/art_2318_27012.html (accessed on 1 April 2021).

6. UNESCO. World Heritage and Buffer Zones. Available online: http://whc.unesco.org/en/documents/101965/ (accessed on 1 April 2021).

7. National Culture Heritage Administration. The Great Wall Resource Survey Workbook. Available online: http://www.ncha.gov cn/art/2007/5/22/art_2318_43428.html (accessed on 1 April 2021).

8. National Culture Heritage Administration. Total Length of the Ming Great Wall. Available online: http://www.ncha.gov.cn/art/ 2009/4/18/art_722_112099.html (accessed on 1 April 2021).

9. Li, Y.; Zhang, Y.; Li, Z. Study on defence system of the Ming Great Wall and military settlements. Archit. J. 2018, 5, 69-75.

10. Li, Y. The Research of Military Fortresses of Nine Defence Areas along the Great Wall in Ming Dynasty. Doctoral Dissertation, Tianjin University, Tianjin, China, 2007.

11. Zhang, Y.; Fan, X.; Li, Y. Wars and the Construction of the Military Settlements along the Great Wall in Ming's Northern Border. J. Tianjin Univ. (Soc. Sci.) 2016, 18, 135-139. [CrossRef]

12. National Culture Heritage Administration. Notice on the Issuance of the First Batch of Important National Sections of the Great Wall. Available online: http:/ / www.ncha.gov.cn/art/2020/11/26/art_2318_44254.html (accessed on 4 April 2021).

13. Chen, Q. Formation and Deployment Strategy of the "Beijing Knot" Defence Line on the Ming Great Wall; China Great Wall Society: Beijing, China, 2007; Volume 3, pp. 26-33.

14. Zhang, T.; Hu, R. The Quality Control and Detection Techniques of Disease Preventive Protection Project of Yuntai in Juyongguan of the Great Wall. Urban. Archit. 2019, 16, 124-127. [CrossRef]

15. Qu, S.; Zhang, T.; Zhao, B.; Wang, J. Diseases of stone relics in Yuntai in the Juyongguan section of the Great Wall. J. Beijing Univ. Chem. Technol. (Nat. Sci.) 2017, 44, 58-65. [CrossRef]

16. Liu, J. The Image of Ghost at the Foot of the King of Heaven in Juyongguan Yuntai. Meiyuan 2014, 1,93-97.

17. Guan, D. Protection and Utilization of Defensive Settlements along the Great Wall in Northwest Beijing. Master's Dissertation, Beijing University of Technology, Beijing, China, 2019.

18. Miao, M. The Research of the Settlements for "Guan Cheng" along the Great Wall in Jizhen Area of Ming Dynasty. Master's Dissertation, Tianjin University, Tianjin, China, 2004.

19. Liu, S. Study on the Defensive Character of Military Settlements in Juyongguan Area of the Great Wall of Ming Dynasty. Doctoral Dissertation, Tianjin University, Tianjin, China, 2011.

20. Yang, Y.; Meng, C. Research on heritage protection system at Great Wall Juyongguan defence area. Shanxi Archit. 2017, 43, 23-24. [CrossRef] 
21. Chen, H.; Dong, Y.; Xiang, Y. The Wall in the Literature. In Chronicles of the Great Wall of China; Jiangsu Phoenix Science and Technology Press: Nanjing, China, 2016; Volume 8, pp. 1609-1774.

22. Wang, S. Annal of Xiguan; Beijing Ancient Books Publishing House: Beijing, China, 1990; p. 12.

23. Liu, X. Annal of the Four Towns and Three Passes; Zhongzhou Ancient Books Publishing House: Zhongzhou, China, 2018; pp. 88-127.

24. Shanghai Bookstore Press. Ming Shi Lu; Shanghai Bookstore Press: Shanghai, China, 2018; Volume 7.

25. ASTER GDEM Global Elevation Data. Available online: https:/ /yceo.yale.edu/aster-gdem-global-elevation-data (accessed on 4 April 2021).

26. Jiang, B.; Brandt, S. A Fractal Perspective on Scale in Geography. Int. J. GEO-Inf. 2016, 5, 95. [CrossRef]

27. Cambridge Business English Dictionary. Rank-Size Rule. Available online: https:/ / dictionary.cambridge.org/dictionary/english/ rank-size-rule (accessed on 8 May 2021).

28. Zhang, H. Self-organized criticality of the spatio-temporal evolution of administrative settlements in Inner Mongolia grassland during Qing Dynasty. J. Arid Land Resour. Environ. 2020, 34, 112-118. [CrossRef]

29. Xiao, K. Fractal Compression and Analysis on Remotely Sensed Imagery. Doctoral Dissertation, Louisiana State University and Agricultural \& Mechanical College, Baton Rouge, LA, USA, 2003.

30. Tan, L.; Zhou, J.; Zhang, Y.; Liu, J.; Liu, H. Correlation between the construction of Zhejiang coastal military settlements in Ming dynasty and natural terrain. J. Coast. Res. 2020, 106, 381-387. [CrossRef]

31. ArcGIS Pro. Create Thiessen Polygons. Available online: https://pro.arcgis.com/en/pro-app/latest/tool-reference/analysis/ create-thiessen-polygons.htm (accessed on 5 April 2021).

32. Cao, Y. Research on Macro Systematic Relationship of Military Settlement of the Three Towns of Xuanfu, Datong and Shanxi along the Great Wall in Ming Dynasty. Doctoral Dissertation, Tianjin University, Tianjin, China, 2015.

33. Cao, Y.; Zhang, Y. Efficient space and resource planning strategies: Treelike fractal traffic networks of the Ming Great Wall Military Defence System. Ann. GIS 2018, 24, 47-58. [CrossRef]

34. Zhang, H. Edge of chaos: Study on the self-organized criticality of the military settlement system along the Great Wall in Ming Dynasty. J. Arid Land Resour. Environ. 2019, 33, 56-64. [CrossRef]

35. The Great Wall of China. Regulations on the Protection of the Great Wall. Available online: http://www.thegreatwall.cn/fagui/ (accessed on 10 May 2021).

36. Yu, J.; Dai, X. Temporal and Spatial Pattern of Cultural Heritage in Beijing-Tianjin-Hebei Region and Its Influencing Factors: A Case Study of Cultural Relic Protection Unit. Econ. Geogr. 2020, 40, 221-230. [CrossRef]

37. Beijing Municipal Administration of Culture Heritage. Beijing Great Wall Cultural Belt Protection and Development Plan. Available online: http:/ / wwj.beijing.gov.cn/bjww/1718401/index.html (accessed on 10 May 2021).

38. Hebei Culture Relics Bureau China. Available online: http:/ / wenwu.hebei.gov.cn/ (accessed on 10 May 2021).

39. National Cultural Heritage Administration. Atlas of Chinese Cultural Relics·Beijing; Science Press: Beijing, China, 2008; Volume 3, pp. 250-285, 338-359, 406-430.

40. National Cultural Heritage Administration. Atlas of Chinese Cultural Relics.Hebei; Science Press: Beijing, China, 2013; Volume 3, pp. 205-215.

41. Badaling News. Available online: http://www.badaling.cn/ (accessed on 13 April 2021).

42. Yu, B. Integral Protection and Management of the Great Wall of China: Challenges and Exploration. Chin. Cult. Herit. 2018, 3, 31-40.

43. Cao, X. The Research on the Transformation and the Modes of Protection and Utilization of the Fortress Settlements along the Great Wall in the Ming Dynasty in Shanxi Province. Doctoral Dissertation, Xi'an University of Architectural and Technology, Xi'an, China, 2014. 